\title{
The Influence of Lateral Confinement Upon the Downstream Gradation in Grain Size of the Lower Ngaruroro River, New Zealand
}

\author{
Michaela Cowie ${ }^{1,2}$ and Gary Brierley ${ }^{*}, 1$ \\ ${ }^{1}$ School of Geography, Geology and Environmental Science, The University of Auckland, Private Bag 92019, Auckland, \\ New Zealand \\ ${ }^{2}$ Present Address: Centre for Catchment and Coastal Research, Institute of Geography and Earth Sciences, University \\ of Aberystwyth, Aberystwyth, Ceredigion, SY23 3DB, Wales, UK
}

\begin{abstract}
Systematic grain size measurements were recorded for all geomorphic units in 41 cross sections spaced 400$800 \mathrm{~m}$ apart along the lower course of the Ngaruroro River. Although the surveyed bed slope has a uniform grade through this reach, valley width imposed by terrace margins increased markedly, with a notable increase $6 \mathrm{~km}$ down-reach. Mean grain size and $\mathrm{D}_{95}$ diminution coefficients of 0.052 and 0.073 were determined for the $19 \mathrm{~km}$ study reach. Marked differences in downstream fining trends were evident for the zones upstream and downstream of $6 \mathrm{~km}$, with significant fining upstream of $6 \mathrm{~km}$ and more subdued fining downstream of $6 \mathrm{~km}\left(\mathrm{D}_{95}\right.$ diminution coefficients of 0.109 and 0.017 respectively). The increase in active channel area associated with the increase in valley width is considered to mark a process control shift from competence-limited to capacity-limited conditions. Selective entrainment rather than abrasion is inferred to be the primary mechanism for downstream fining. Lateral confinement also affects patterns of geomorphic units. The competence-limited environment (upstream $6 \mathrm{~km}$ ) comprises stabilised bars, stabilised gravel sheets and gravel sheets while the capacity-limited environment (downstream of $6 \mathrm{~km}$ ) is characterised by significant lateral variability of gravel sheets, high flow chutes, ridges, ramps, platforms, stabilised bars and stabilised gravel sheets. Findings from this study highlight the importance of lateral confinement as a control on river processes and forms.
\end{abstract}

Keywords: Lateral confinement, competence limit, capacity limit, downstream fining, geomorphic unit, bed material size, gravel bed river.

\section{INTRODUCTION}

The bedload fraction is a key determinant of hydraulic relationships and channel morphology in gravel bed rivers. At the reach scale, channels adjust to imposed water and sediment supply through mutual interactions of channel form, local grain size, and local flow dynamics which govern bed mobility [1]. Entrainment and transport are generally regarded as size selective with a proportional relationship between the maximum mobile particle diameter and the shear stress exerted by the flow, which in turn is dependent upon the discharge and the slope [2]. Controls on entrainment, namely bed composition, local flow and sediment supply, are non linear and interactive in nature [3]. Hence, bed material configuration both reflects and produces the variable nature of gravel entrainment from naturally sorted gravel bed rivers [4].

The composition of heterogeneous grain size distributions in river systems reflects their source, the rate of sediment supply, the flow regime, and the history of sediment transport and deposition [5-7]. Some systems are competence-limited, whereby gravel fractions are too coarse to be entrained by the available discharge $[8,9]$. The coarsest grain size fraction along a reach is indicative of the competence limits within the channel [6]. Elsewhere, there is insuf-

*Address correspondence to this author at the School of Geography, Geology and Environmental Science, The University of Auckland, Private Bag 92019, Auckland, New Zealand; E-mail: g.brierley@auckland.ac.nz ficient energy for the river to transport all available gravel fractions in capacity-limited systems; there is too much sediment for the river to transport $[9,10]$.

Fluvial systems are inherently part of a morphological continuum in which upstream controls determine the available discharge and sediment supply, such that grain size trends vary markedly in source, transfer and accumulation zones $[11,12]$. Three sets of processes contribute to downstream fining: abrasion, selective transport/hydraulic sorting and weathering [13]. Weathering is generally dismissed as being a relatively minor component of the reduction in grain size [14]. Abrasion is a summary term covering the mechanical breakage of gravel clasts during transport and in situ jostling', which increases the prospects for preferential entrainment of smaller sized particles [14-16]. However, abrasion alone cannot account for the degree of downstream fining and selective transportation provides a more effective basis to account for downstream trends in grain size [17-21]. Selective entrainment entails the differential and preferential entrainment and transport of gravel clasts [22]. The ability of the river to entrain and transport sediment is a function of stream power and shear stress, both of which are determined largely by slope. As shear stress and stream power decline, larger particles are progressively no longer able to be entrained, and are deposited out of the flow. Presuming that discharge remains constant, flow competence decreases as slope declines. A highly concave longitudinal profile produces a rapid downstream decrease in shear stress, forcing selective deposition [23]. Sorting by size or weight during 
transport produces distinct depositional structures common to gravel-bed rivers, such as barhead-to-tail fining [24], lateral fining [25], vertical armouring [26] and downstream fining [19].

Catchment geology influences the nature and amount of sediment delivered to a stream, the rate at which material breaks down, and hence the pattern of downstream fining $[23,27,28]$. The degree to which abrasion or selective transportation dominate as controls upon rates of downstream fining is dependent upon the susceptibility of the gravel clasts to abrasion. Rates of downstream diminution vary for different lithologies [14, 21, 28, 29]. Size-selectivity and rate of downstream fining decrease with increased sediment supply to the channel [30]. Sediment inputs from tributaries and lateral 'non-point' sources (e.g. alluvial fans, hillslope material) may disrupt patterns of downstream fining in grain size along the trunk stream, producing discrete 'sedimentary links' along some rivers (e.g. [31-36]). Also, moving downstream the proportion of differing rock types varies from sample to sample [30].

Gravel organisation is concerned not only with slope variation associated with the distribution of stream power and shear stress, but also with the way that energy is utilized across the valley floor. Lateral confinement of the channel is a key determinant of the depth of inundation and the energy distribution across the valley floor at differing flow stages $[37,38]$. As energy is not used evenly across the valley floor, flow selectively sorts materials, affecting patterns of downstream fining (e.g. [39]).

This research investigates the role of lateral confinement as a control on gravel organisation and grain size distribution in a braided river system. Variability in grain size at the geomorphic unit scale is related to longitudinal grain size trends along the lower course of the Ngaruroro River in Hawke's Bay, New Zealand. The study reach extends from an upstream gorge through a reach subjected to variable lateral confinement by Quaternary terraces.

\section{REGIONAL SETTING}

The Ngaruroro River is an actively aggrading gravel bed river on the East Coast of the North Island, New Zealand (Fig. 1a). It drains a catchment area of more than $2900 \mathrm{~km}^{2}$ with a trunk stream length of $173 \mathrm{~km}$. The upstream course of the Ngaruroro is constrained within a deeply dissected, highly faulted landscape $[40,41]$. Tectonic activity in the catchment reflects its proximity to the Hikurangi margin [40, 41]. The Ngaruroro Catchment broadly comprises greywacke of varying ages [41], with a limited distribution of ash, mudstone and limestone. The longitudinal profile has a classic concave-upwards shape (Fig. 1b). The study reach, which extends from the gorge section immediately upstream of Whanawhana to the less laterally confined terrace section upstream of Maraekakaho, has a uniform channel gradient of $0.0004 \mathrm{~m} / \mathrm{km}$ (inset on Fig. 1b).

Uplifted flights of terraces that range from 20-100 m high confine the lower course of the Ngaruroro River [40]. The terraces comprise Heretaunga alluvium, fossiliferous marine sands and greywacke interlaced with fluviatile sand and silts [42]. Preservation of terrace flights reflects local and regional uplift and oscillating climatic conditions between glacial (aggradational) and interglacial (degradational) periods [42]. Fluvial and marine deposits bury terraces in downstream sections of the Heretaunga Plains.

As the channel emerges from the gorge, it displays a series of alternating bars (Fig. 2a). Downstream from Whanawhana (located on Fig. 1) the Ngaruroro River adopts a mixed braided-wandering gravel bed channel planform (Fig. $\mathbf{2 b}, \mathbf{c}$ ), with floodplain pockets at the margins of the active channel zone in wider sections. The braided planform extends downstream to Maraekakaho (Fig. 1). Extensive flood emban kments line the channel in lowland reaches that lie beyond the study reach.

The catchment stretches across the rain shadow of the Kaimanawa and Kaiwaka Ranges which have an annual average rainfall of 2000-3500 $\mathrm{mm}$, to the coastal regions which receive an average of $800-1000 \mathrm{~mm}$ [43]. Annual average peak flows occur in September $\left(150 \mathrm{~m}^{3} \mathrm{~s}^{-1}\right)$ and the period of lowest flow occurs from January to April $\left(19-26 \mathrm{~m}^{3} \mathrm{~s}^{-1}\right)$ [43].

\section{METHODS}

The study reach extends from the upstream gorge to downstream relatively unconfined sections (Fig. 1b). The downstream margin was determined by the upstream extent of anthropogenic management practices and flood protection measures employed by the Hawke's Bay Regional Council. Within this reach, 41 sampled cross sections were spaced at 400-800 m apart (see Fig. 1c). This interval provided sufficient resolution to capture the variable nature of confinement, channel pattern and gravel organisation within the reach. The cross sections were aligned perpendicular to terraces to capture the lateral variability of geomorphic units across the active channel zone. Field sampling was undertaken at low flow stage (January to March, 2006).

All cross sections were surveyed and the coarsest fraction was systematically sampled for each geomorphic unit on the section. This coarsest fraction most closely represents the upper threshold for entrainment, thereby providing a measure of the geomorphic effectiveness of flow [44]. The Wolman transect method was used as it provides a consistent level of data capture through the reach $[31,45]$. Transects were aligned in the direction in which the geomorphic unit was deposited. Samples of 50 clasts were systematically collected from the coarsest depositional locale upon each geomorphic unit in the cross section (typically the head of the geomorphic unit), following procedures documented by [19]. All geomorphic units that dissected a given cross-section were sampled. This design captures both downstream trends within the study reach and representative variability in grain size across any given cross-section (i.e. lateral trends). Grain size analyses were truncated at $8.0 \mathrm{~mm}$, as the smaller grain size fractions were considered to be transported as suspended load $[19,45]$. The truncation of the grain size analysis also limited the bias inherent in sampling and handling of finer grain size fractions [46]. To minimize bias, the differentiation and identification of geomorphic units, and all field measurements, were performed by a single operator.

The differentiation of geomorphic units reflected the morphology of each feature, its position within the channel, and its elevation relative to surrounding units and the thalweg [47]. The degree and type of vegetation is indicative of 

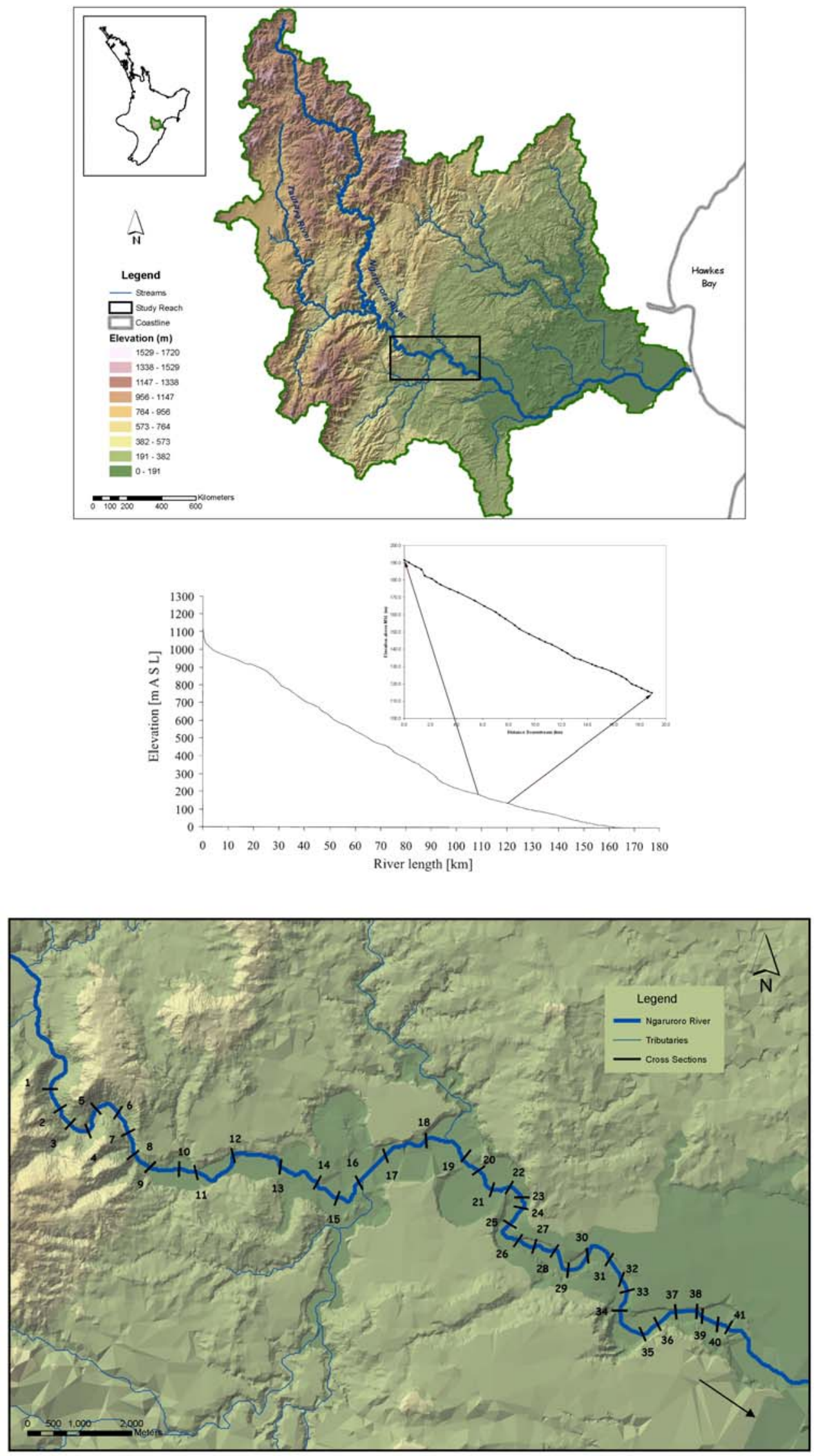

Fig. (1). (a) study reach, (b) long profile of catchment (modified from Segschneider et al., 2002) and study reach, and (c) sample crosssection locations. Terrain data source: Land Information New Zealand. 
(a)

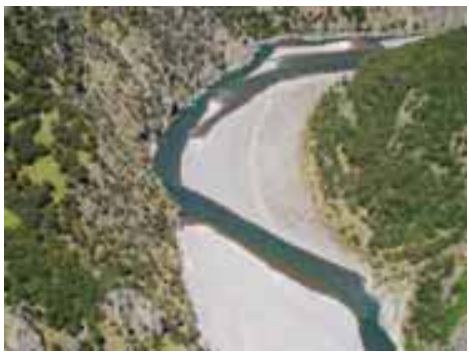

(b)

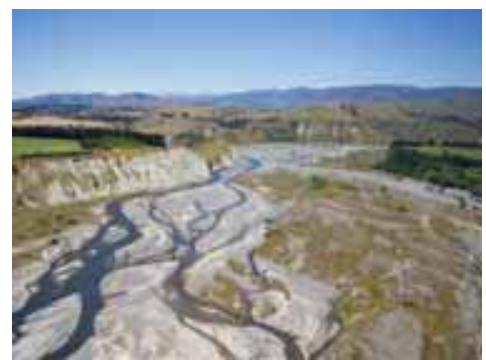

(c)

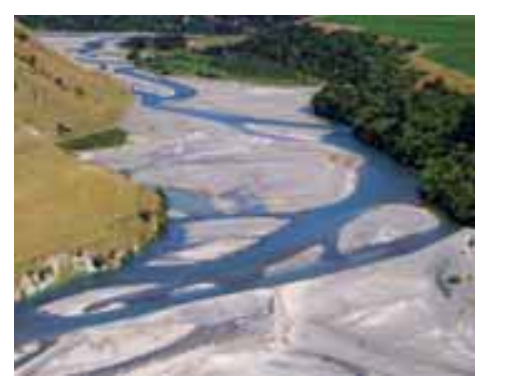

Fig. (2). Representative photographs of the study reach. (a) Alternating bars of the Ngaruroro River as it emerges from the gorge. (b) Braided reach. (c) Wandering gravel-bed river reach.

the relative stability of the surface, enabling differentiation of within-channel and floodplain surfaces and stabilised bars and stabilised gravel sheets. Floodplains were differentiated from the active channel zone by their elevation above the thalweg, degree of soil cover and fine-grained materials, and vegetation cover (typically grasses, shrubs and larger trees). These latter surfaces were not included in the grain size analyses, as this study focused upon the active gravel fraction within the channel zone.

Standard grain size parameters $\left(\mathrm{D}_{95}, \mathrm{D}_{84}\right.$, mean, median and sorting (measured as standard deviation)) were determined for each sample. Downstream fining coefficients were calculated from Sternberg's Law by fitting an exponential function relationship trendline through the mean and coarsest $\left(\mathrm{D}_{95}\right.$ and $\left.\mathrm{D} 84\right)$ grain size fractions [14]. Lateral variability in grain size was assessed using the mean grain size and $0.5 \phi$ modal group of each geomorphic unit in each cross-section. These data provide insight into how energy is used across the active channel zone.

\section{RESULTS}

\section{Longitudinal Grain Size Trends}

The mean grain size of the coarsest geomorphic unit in each cross-section decreases from $126 \mathrm{~mm}$ at the upstream extent of the study reach to $27 \mathrm{~mm}$ at the downstream point (Fig. 3). This downstream trend is best represented by an exponential function which has an $r^{2}$ value of 0.74 (the linear relationship has an $\mathrm{r}^{2}$ value of 0.71 ). Fig. (3) shows a marked decline in grain size from $0-6.0 \mathrm{~km}$, and a more subdued trend from $6.0-19.0 \mathrm{~km}$ (i.e. the rate of decline becomes less pronounced). Pronounced local variation is evident around the general declining trend. The sorting of the coarsest geomorphic units decreases downstream as grain size decreases. As shown for the mean grain size, sorting is improved and more consistent downstream of $6 \mathrm{~km}$ (Fig. 3).

The coarsest grain size fractions $\left(\mathrm{D}_{95}\right.$ and $\left.\mathrm{D}_{84}\right)$ have more pronounced downstream fining trends (Fig. 4). The steeper observed trend of decreasing grain size in the $\mathrm{D}_{95}$ and $\mathrm{D}_{84}$ grain size fractions are best represented by exponential functions ( $r^{2}$ of 0.69 and 0.73 respectively), with downstream fining coefficients of 0.049 and 0.052 respectively. The more subdued and consistent fining of the median grain size fraction $\left(D_{50}\right)$ is best represented linearly, with an $r^{2}$ value of 0.67 . The rate of downstream fining for the coarsest grain size fraction and the mean grain size are very similar $(0.05$;
Figs. (3) and (4)). The downstream distance over which a halving of the coarsest and mean grain size occurs is around $6.0 \mathrm{~km}$.

Figs. (3) and (4) demonstrate a clear transition in downstream fining trends at $6.0 \mathrm{~km}$. Fig. (5) shows revised trends and coefficients upstream and downstream of this point. The coarsest fraction samples collected upstream of $6 \mathrm{~km}$ have a mean grain size of $90.3 \mathrm{~mm}$ while the mean grain size for the downstream group is $47.0 \mathrm{~mm}$. Error bars on box plots for these populations do not overlap and Levene's test for equality of variance indicates that they are significantly different statistical populations ( 0.05 confidence interval). Similar sets of statistically significant results are derived for the $\mathrm{D}_{95}$ grain size statistic (183.5 and $96.5 \mathrm{~mm}$ respectively for the populations upstream and downstream of $6.0 \mathrm{~km}$ ). The upstream reach has a downstream fining coefficient of $0.11\left(\mathrm{D}_{95}\right.$ and $\left.\mathrm{D}_{84}\right)$, notably higher than the fining coefficients of $0.02\left(\mathrm{D}_{95}\right.$ and $\mathrm{D}_{84}$ ) downstream of the transition zone (Fig. 5). The median grain size $\left(D_{50}\right)$ is best represented by consistent linear downstream decline in median grain size, with an $r^{2}$ value of 0.67 (Figs. 4 and 5).

Half-phi histograms showing the grain size distribution for the coarsest geomorphic units in the study reach are presented in Fig. (6) upstream of $6.0 \mathrm{~km}$, the $91-128 \mathrm{~mm}$ and $128-181 \mathrm{~mm}$ classes are the modal group in 6 and 5 of the 13 samples respectively. Downstream of $6.0 \mathrm{~km}$, the $45-64 \mathrm{~mm}$ class is the modal group in 17 of 28 samples. Very few clasts coarser that $128 \mathrm{~mm}$ were recorded downstream of $6.0 \mathrm{~km}$ (Figs. 4 and 6).

\section{Lateral Grain Size Trends}

Lateral variability in the make-up of geomorphic units and their modal 0.5 phi grain size is shown schematically for each cross section in the study reach in Fig. (7). The mixed nature of lateral grain size trends attests to the recurrent reworking of the active channel zone by shifting channels. Gravel sheets are the dominant geomorphic unit. Often, multiple features are evident at differing positions and elevations in a cross-section. Pebble sized clasts $(16-64 \mathrm{~mm})$ are the modal grain size class for all geomorphic units within the study reach (Table 1). Ramps are the coarsest grained features followed by stabilised bars. Gravel sheets, ridges, high flow chutes and stabilised gravel sheets have similar mean grain size, while bar platforms have the finest mean grain size. However, there is a significant range in mean grain size for all geomorphic units other than platform deposits. In 


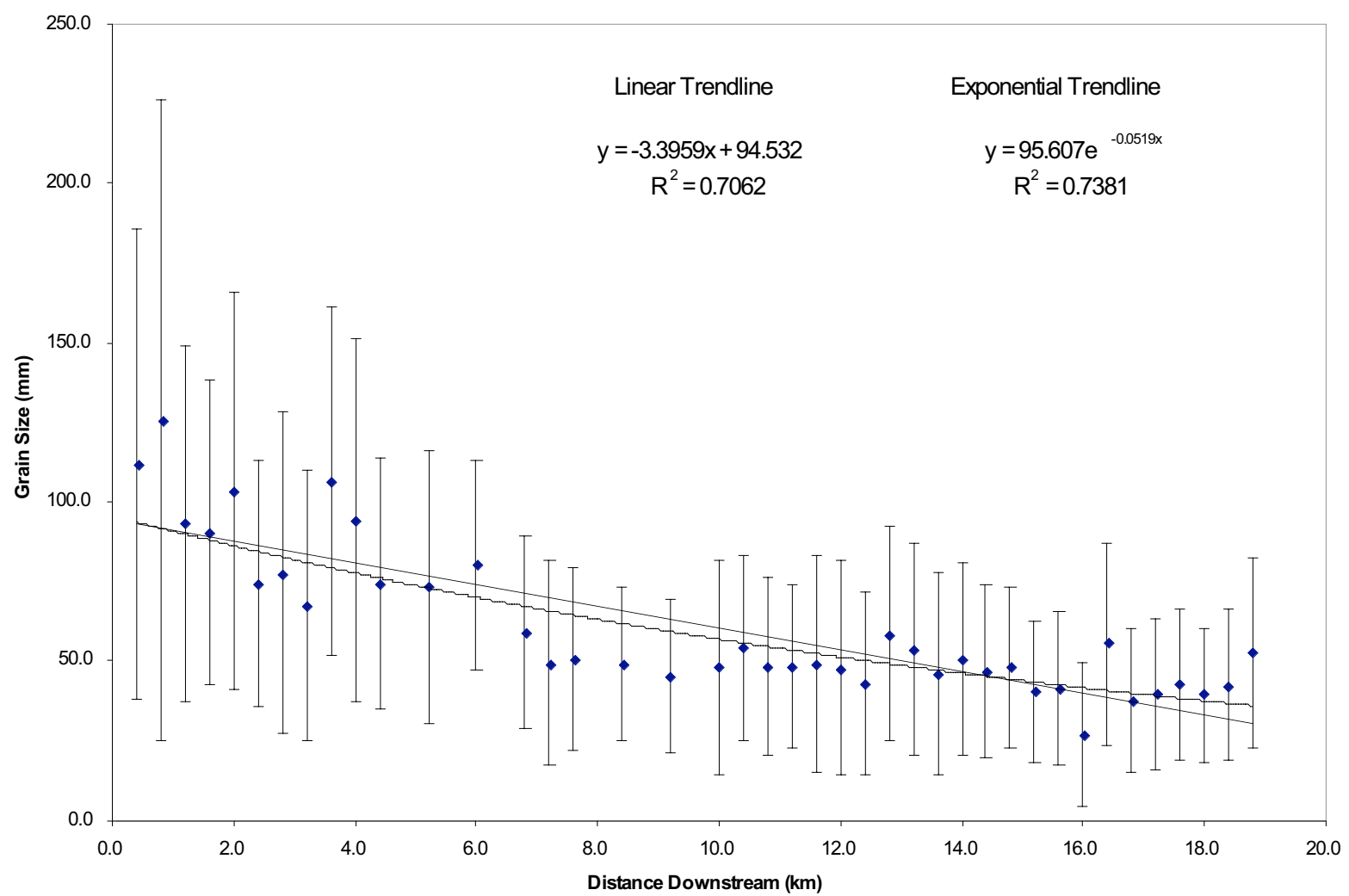

Fig. (3). Downstream variation of coarsest geomorphic unit mean grain size and sorting through the study reach, from the upstream section at $0.4 \mathrm{~km}$ to the final observed site at $18.8 \mathrm{~km}$ downstream. Each error bar represents one standard deviation in the mean grain size of the coarsest gravel clast population. The mean grain size data are fitted with a linear and power function relationship trendline. The equation of the line and r-square values are shown.

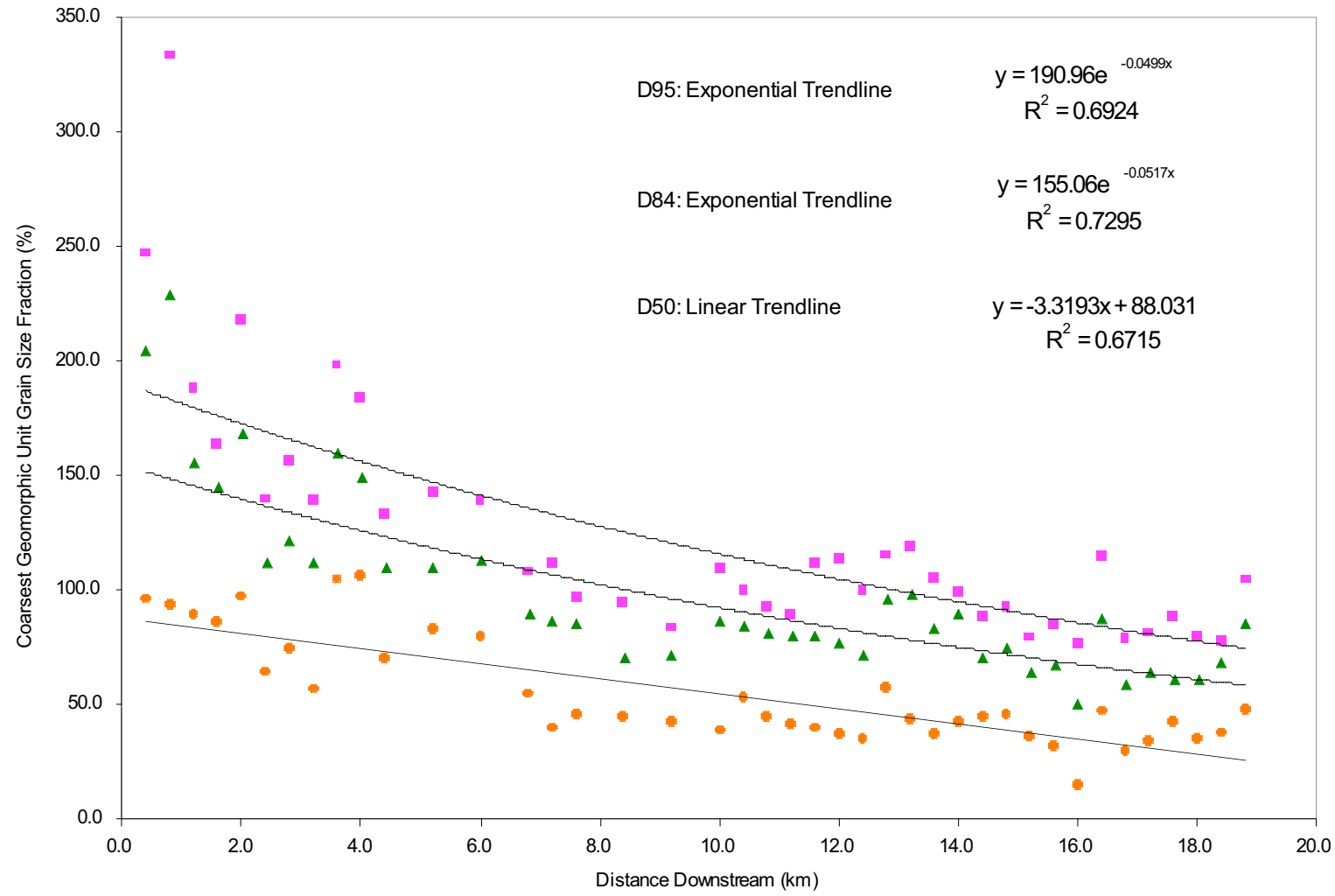

Fig. (4). Coarse grain size fraction variation through the study reach: $95^{\text {th }}$ percentile $\left(D_{95}\right)$ [squares], the $84^{\text {th }}$ percentile $\left(D_{84}\right)$ [triangles] and the $50^{\text {th }}$ percentile $\left(\mathrm{D}_{50}\right)$ or median grain size [circles]). The $\mathrm{D}_{95}$ and $\mathrm{D}_{84}$ grain size fractions are best-fitted with an exponential function relationship trendline, and the median grain size or $\mathrm{D}_{50}$ is best-fitted with a linear function relationship trendline. 


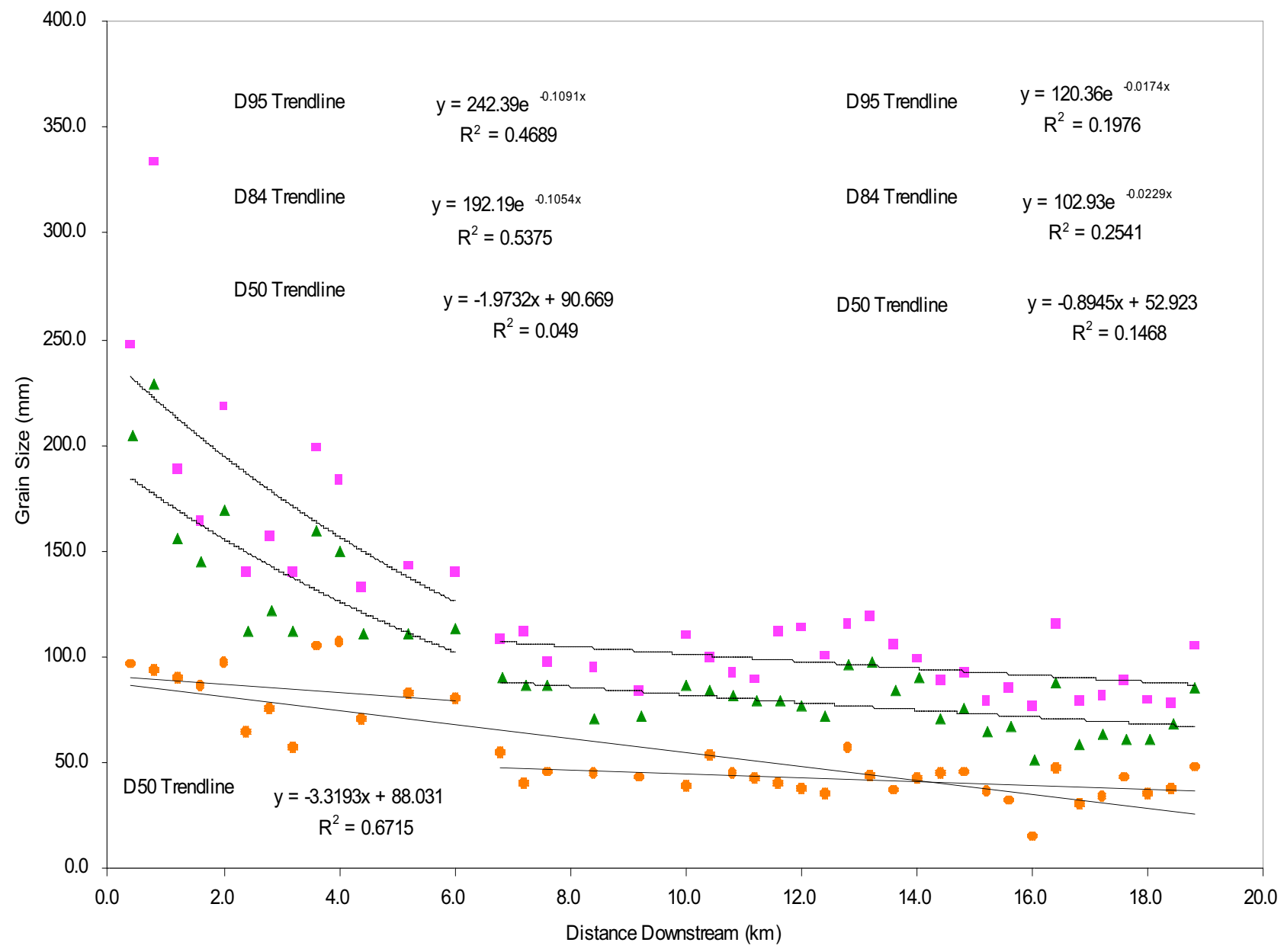

Fig. (5). Downstream variation in the coarse grain size fraction: $\left(D_{95}\right.$ squares, $D_{84}$ triangles and the $D_{50}$ circles). This Fig. illustrates the location of the transition zone at $6.4 \mathrm{~km}$ through the study reach. The coarse grain size fractions $\left(\mathrm{D}_{95}\right.$ and $\left.\mathrm{D}_{84}\right)$ are fitted with exponential function relationship trendlines accounting for the differential fining upstream and downstream of the transition zone within the study reach. The median grain size fraction $\left(\mathrm{D}_{50}\right)$ has been fitted with both linear function relationship trendlines.

summary terms, the mean grain size decreases down-reach for each geomorphic unit, but there is pronounced local-scale variability in this trend. A range of geomorphic units may be observed at differing elevations and position relative to the thalweg in any given cross-section, with variation in the 0.5 phi modal grain size class extending over several phi units (Fig. 7)

\section{DISCUSSION}

The downstream trend of grain size through the study reach demonstrates a classic exponential pattern, similar to that predicted by Sternberg's Law. However, there is a distinct break in this trend at $6.0 \mathrm{~km}$ (Fig. 5). The sharp fining of grain size observed within the upstream $(0-6 \mathrm{~km})$, relative to the section downstream, reflects the pre-eminence of selective entrainment, winnowing and preferential entrainment of finer fractions within the bed. The downstream section has diminished fining trends and more uniform grain size. This pattern cannot be explained in terms of discrete 'sedimentary links' generated by 'non-point source' inputs of material.
As slope is consistent throughout the study reach (inset on Fig. 1b), this factor cannot account for the observed patterns of downstream fining. By extension, this pattern cannot be explained in terms of changes to total stream power. Rather, the change in downstream grain size trends reflects the shift from the more laterally confined gorge section of the study reach to the more alluvial, less laterally confined section. The shift in grain size is mirrored by the decreasing lateral confinement and broadening of the active channel zone downstream of $6.0 \mathrm{~km}$, and an associated dissipation of flow energy (i.e. reduced unit stream power). Differing assemblages of geomorphic units and grain size trends mark this shift in behavioural regime. The shift in geomorphic unit grain size as shown on histogram plots (Fig. 6) indicates that a competence limit is reached at $6.0 \mathrm{~km}$, such that the coarser grain size fractions (181-256 $\mathrm{mm}$ and 257-362 $\mathrm{mm}$ ) are seldom transported downstream. Alternatively, these clasts may be buried beneath more mobile, finer grained gravel fractions. Fig. (8) shows the strong correlation between lateral confinement and mean grain size through the study reach. The relationship is best characterised by a logarithmic function. 


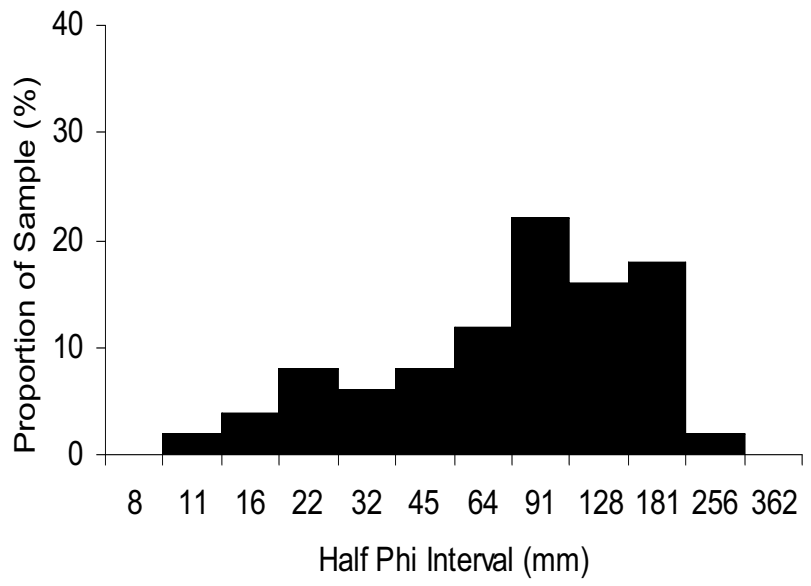

Site 1: $0.4 \mathrm{~km}$

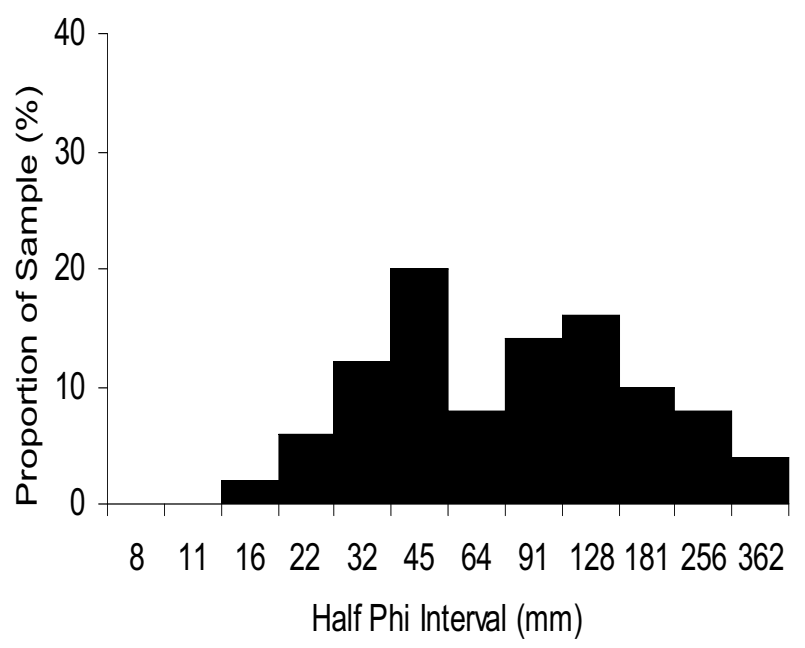

Site 2: $0.8 \mathrm{~km}$

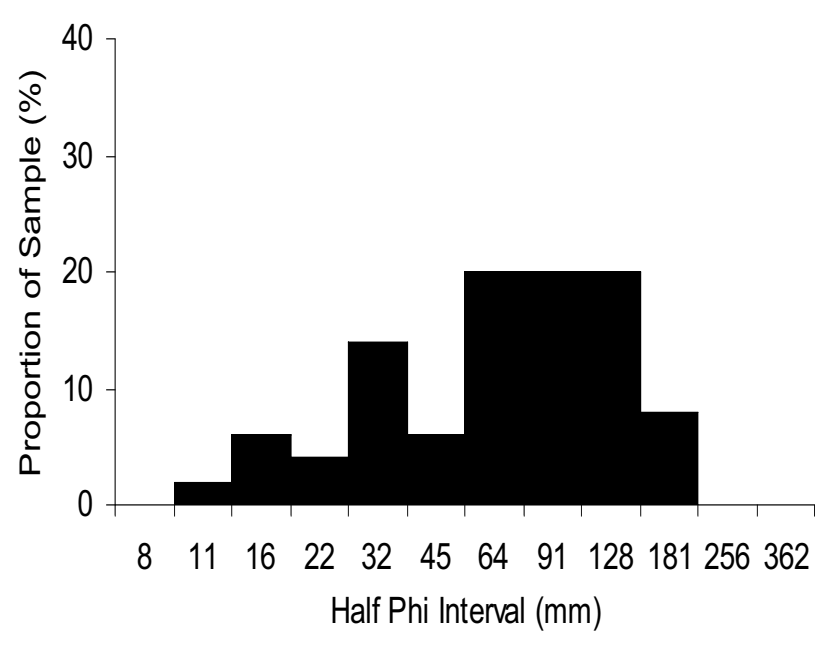

Site 3: $1.2 \mathrm{~km}$
(Fig. 6) contd......

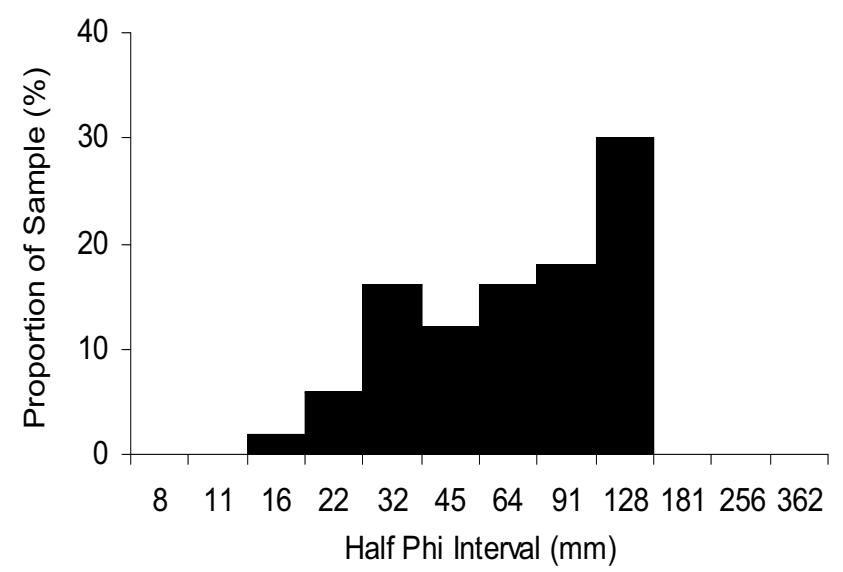

Site 4: $1.6 \mathrm{~km}$

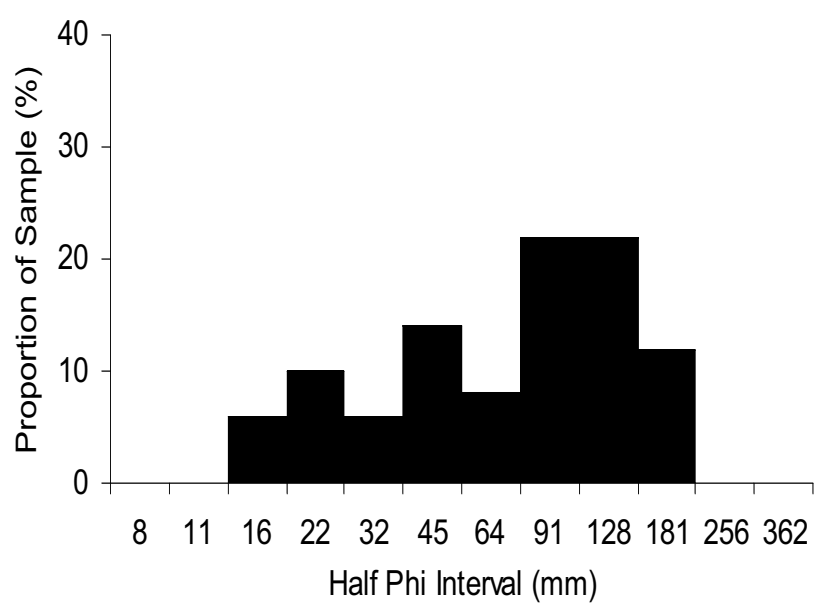

Site 5: $2.0 \mathrm{~km}$

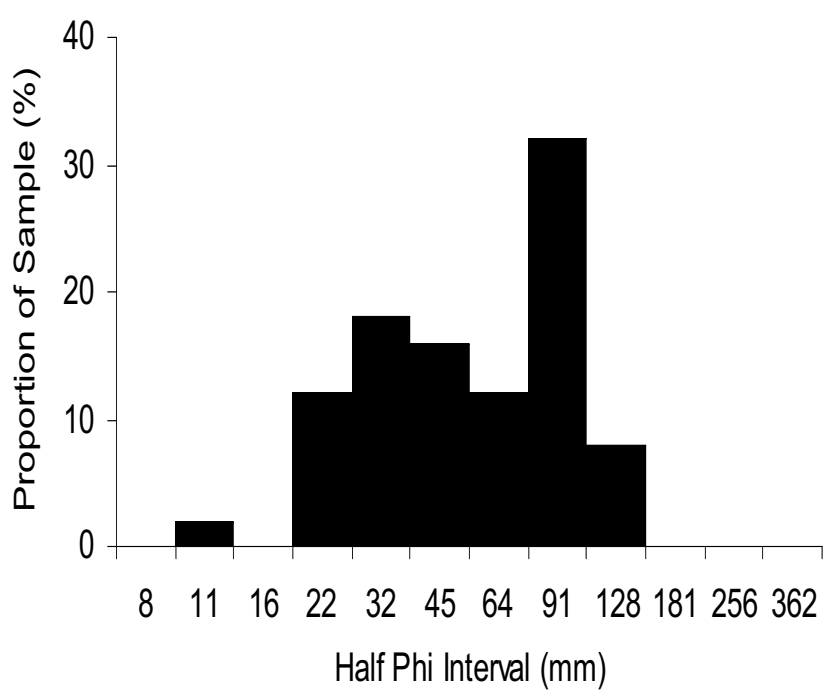

Site 6: 2.4 km 


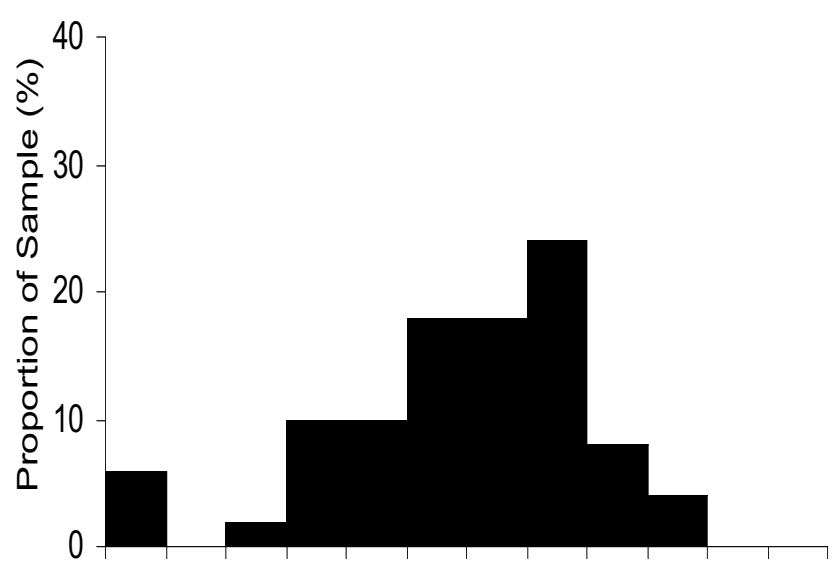

$\begin{array}{llllllllllll}8 & 11 & 16 & 22 & 32 & 45 & 64 & 91 & 128 & 181 & 256 & 362\end{array}$ Half Phi Interval (mm)

Site $7: 2.8 \mathrm{~km}$

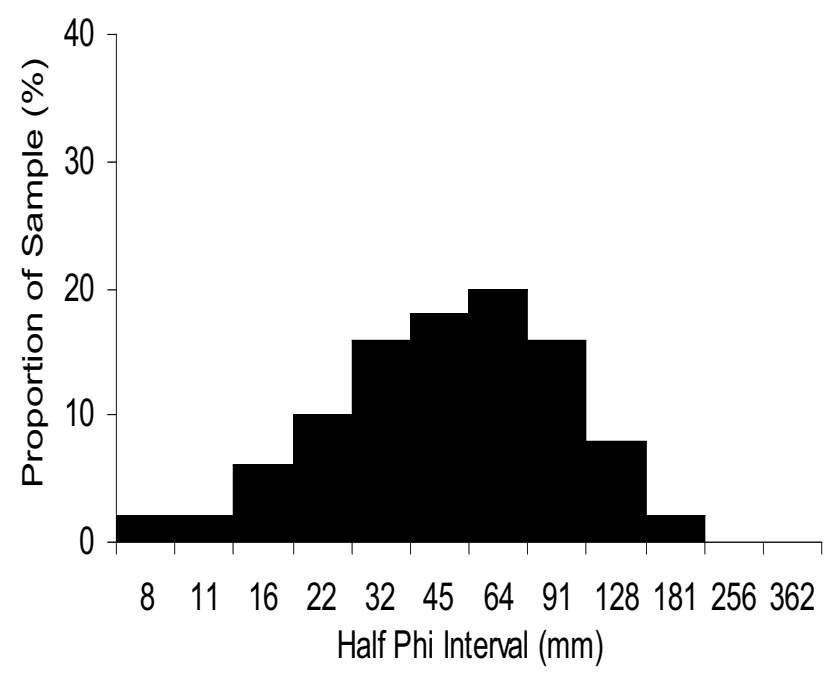

Site 8: $3.2 \mathrm{~km}$

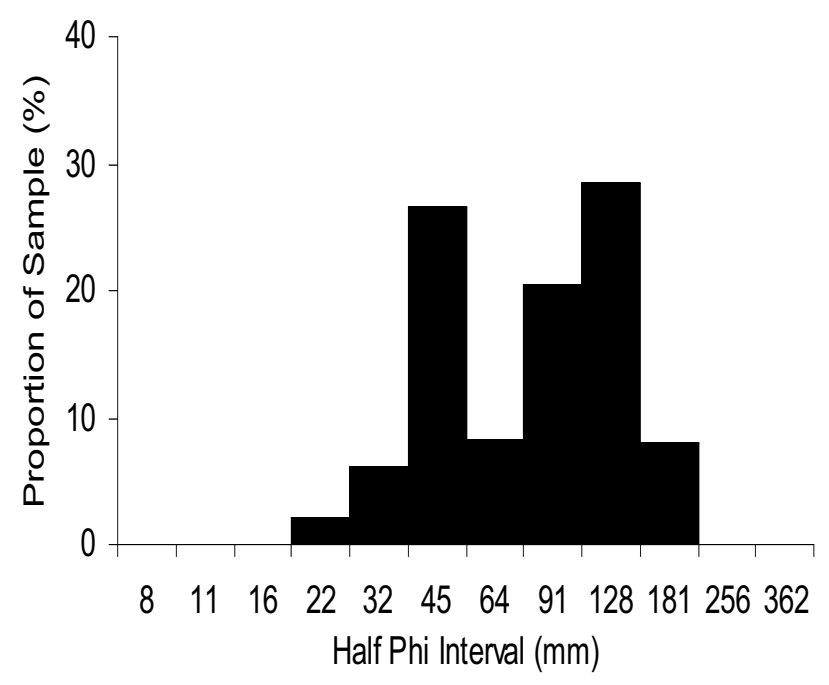

Site 9: $3.6 \mathrm{~km}$

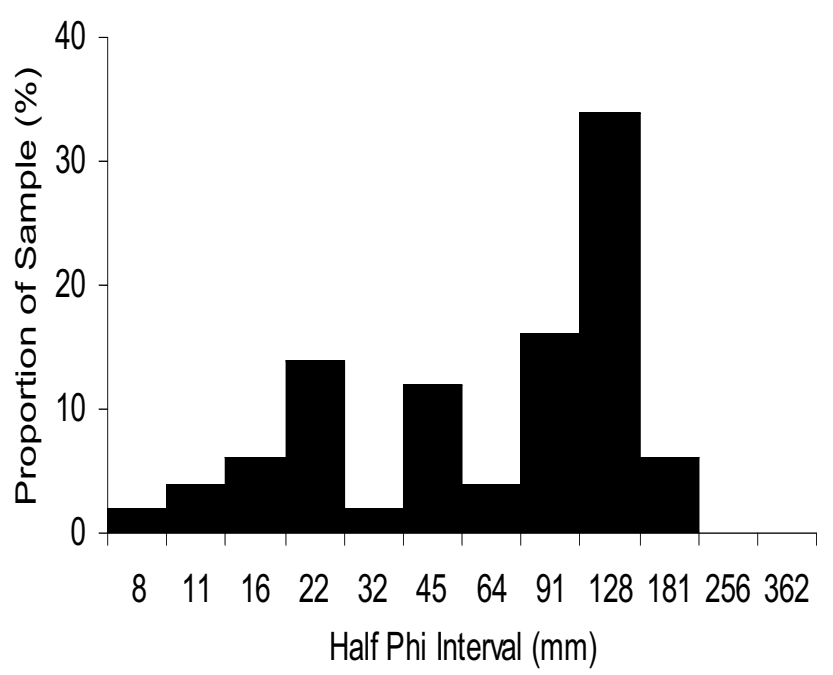

Site 10: $4.0 \mathrm{~km}$

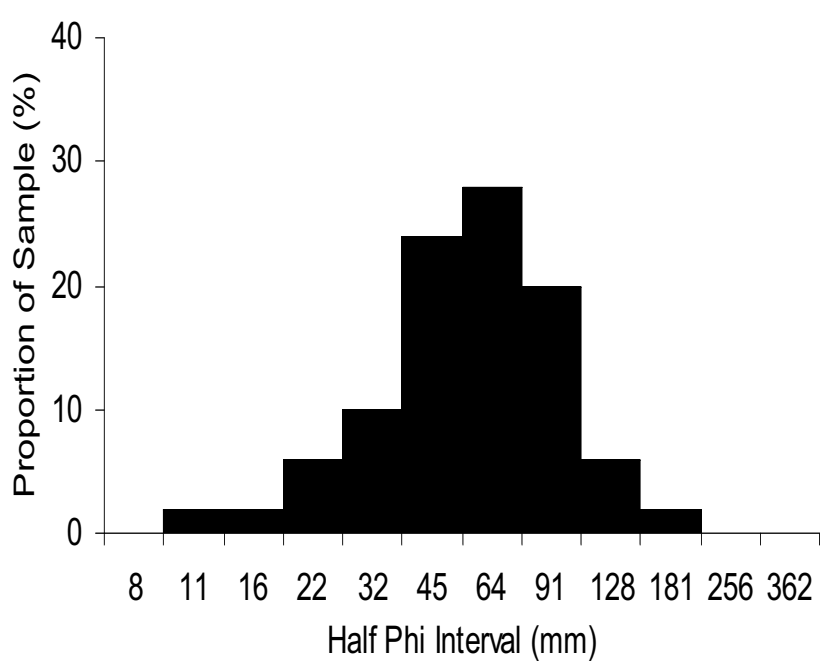

Site 11: $4.4 \mathrm{~km}$

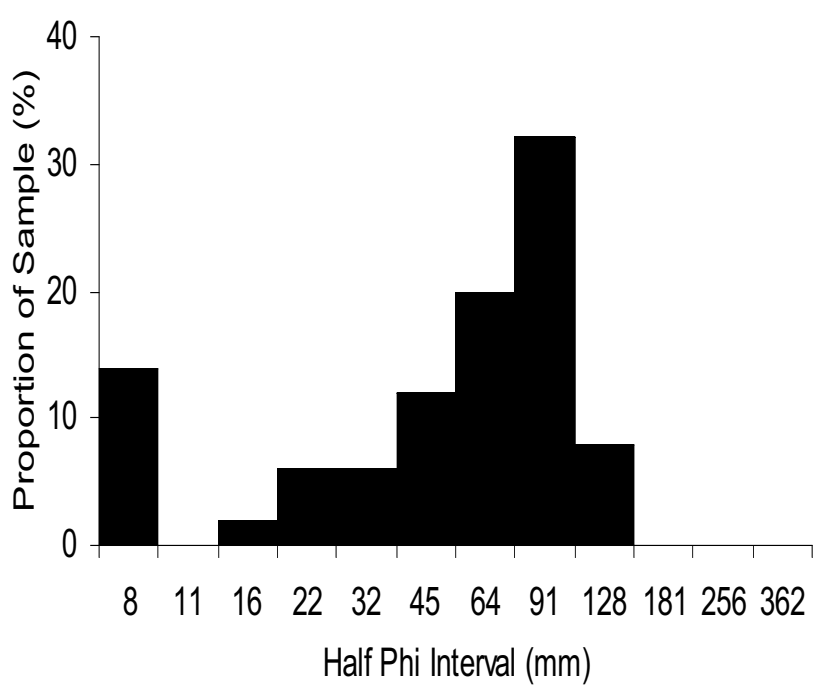

Site 12: $5.2 \mathrm{~km}$ 
(Fig. 6) contd.....

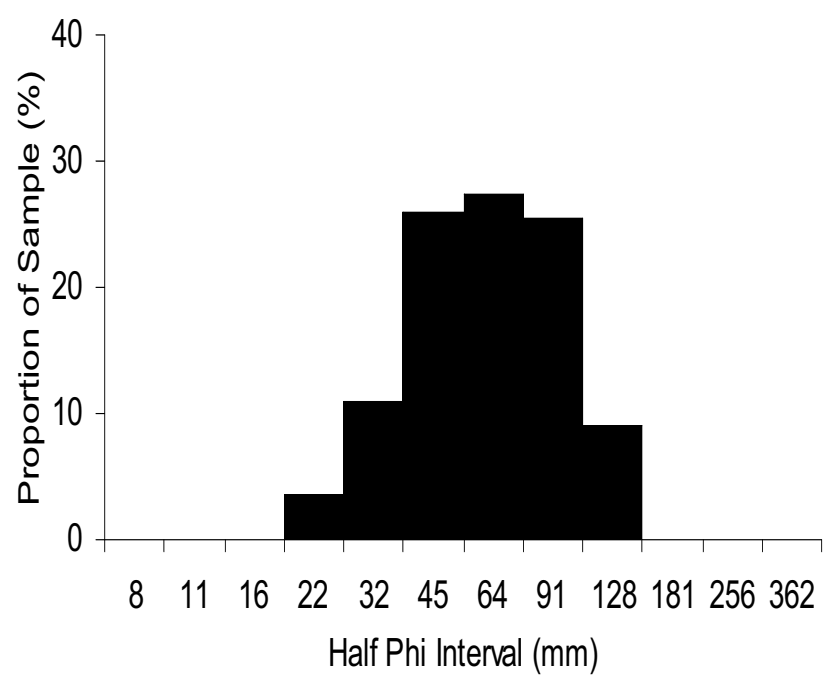

Site 13: $6.0 \mathrm{~km}$

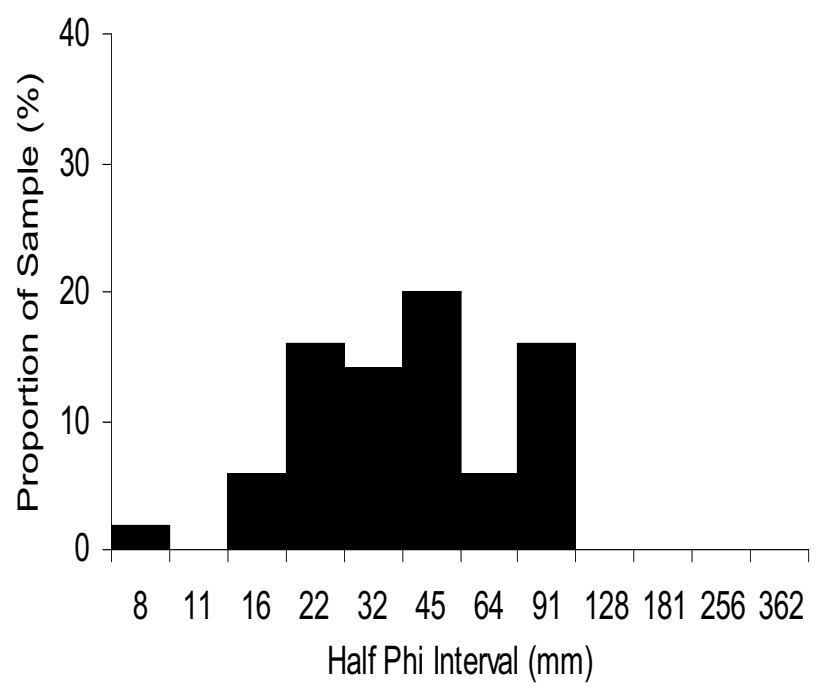

Site 14: $6.8 \mathrm{~km}$

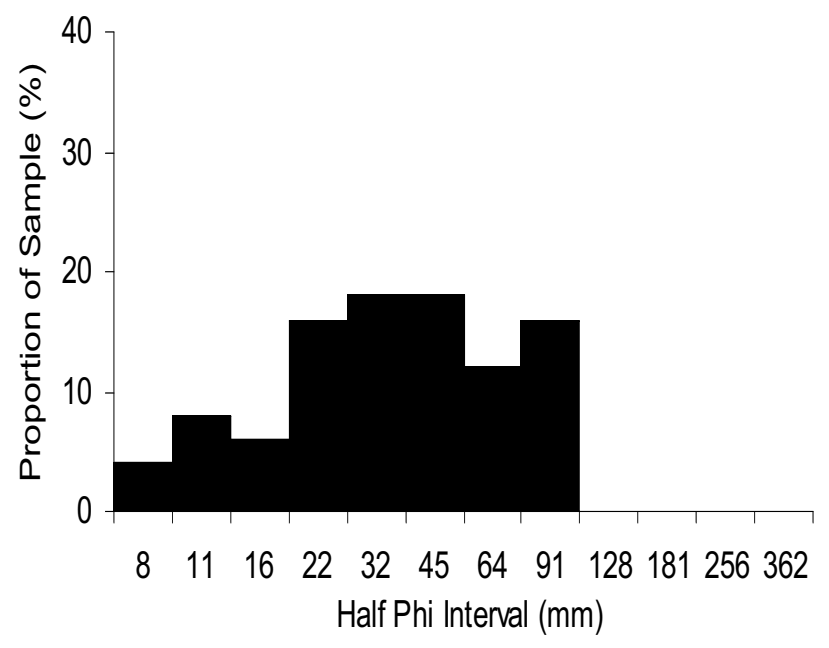

Site 15: $7.2 \mathrm{~km}$
(Fig. 6) contd......

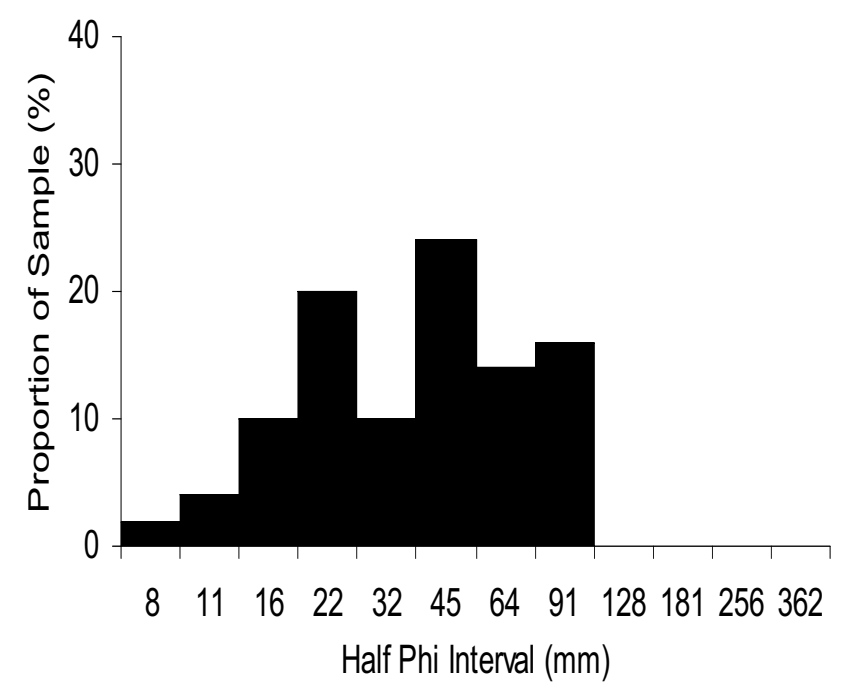

Site 16: $7.6 \mathrm{~km}$

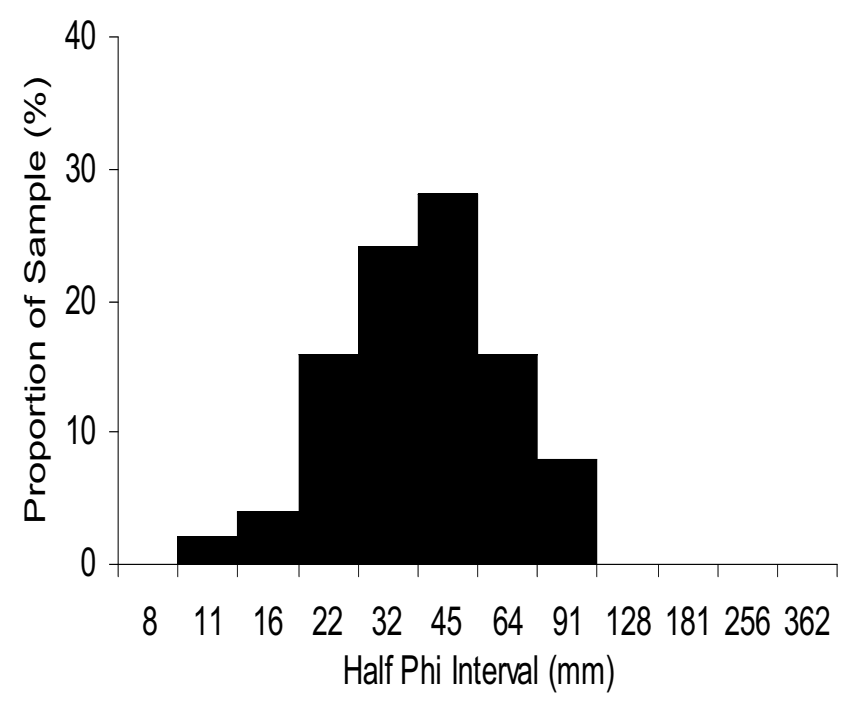

Site 17: $8.4 \mathrm{~km}$

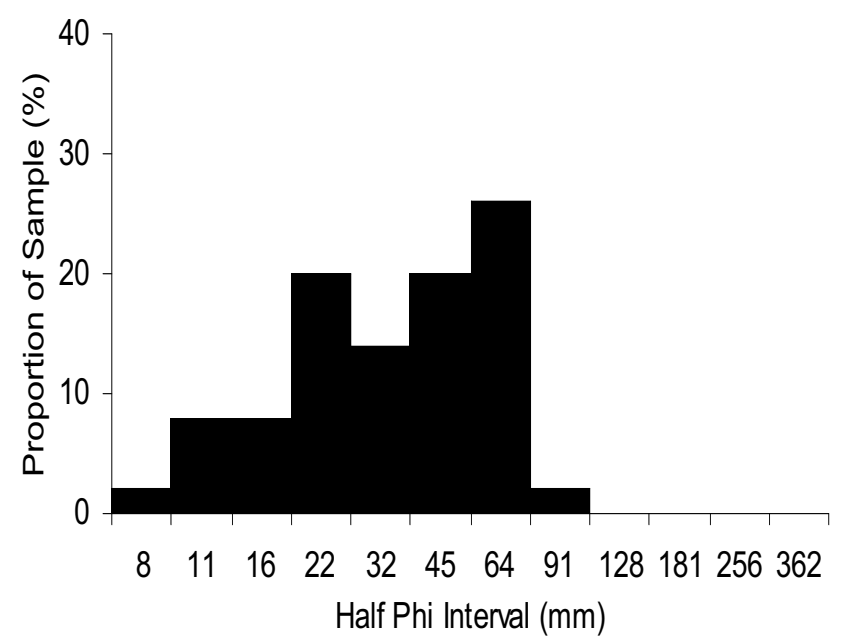

Site 18: $9.2 \mathrm{~km}$ 
(Fig. 6) contd.....

(Fig. 6) contd.....

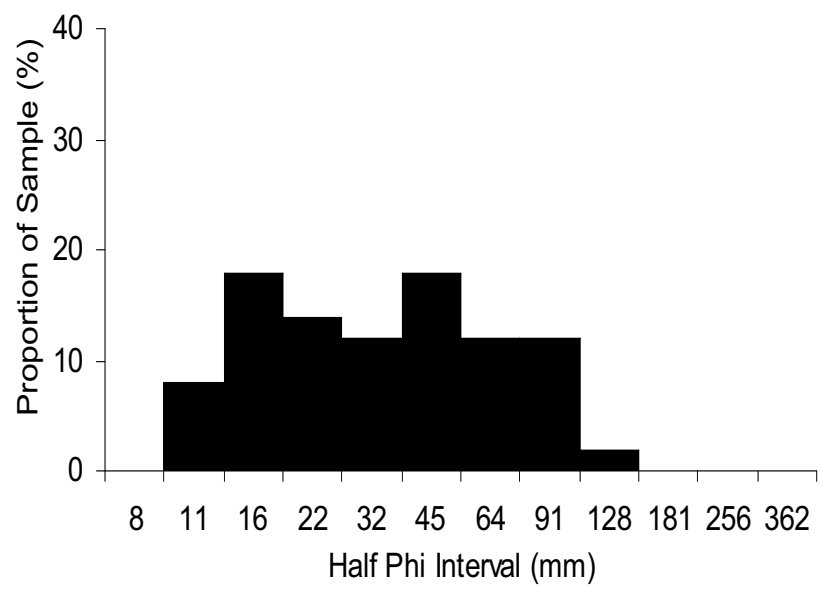

Site 19: $10.0 \mathrm{~km}$

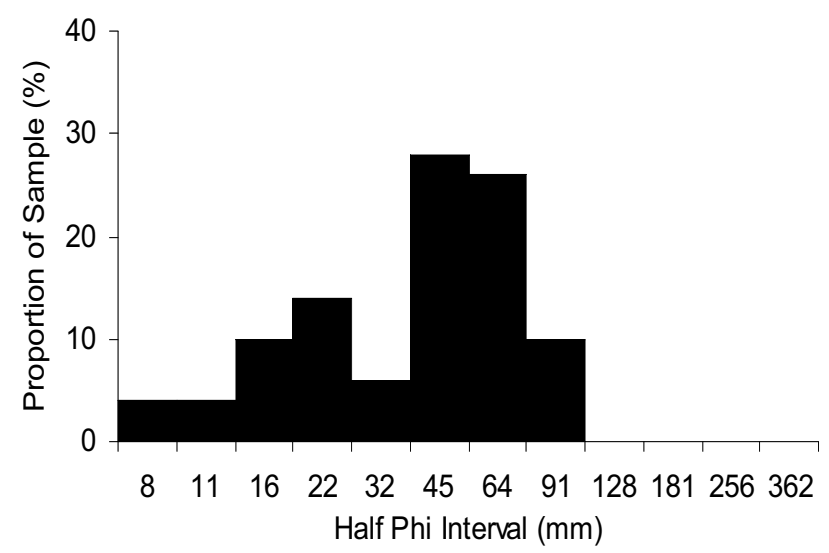

Site 20: $10.4 \mathrm{~km}$

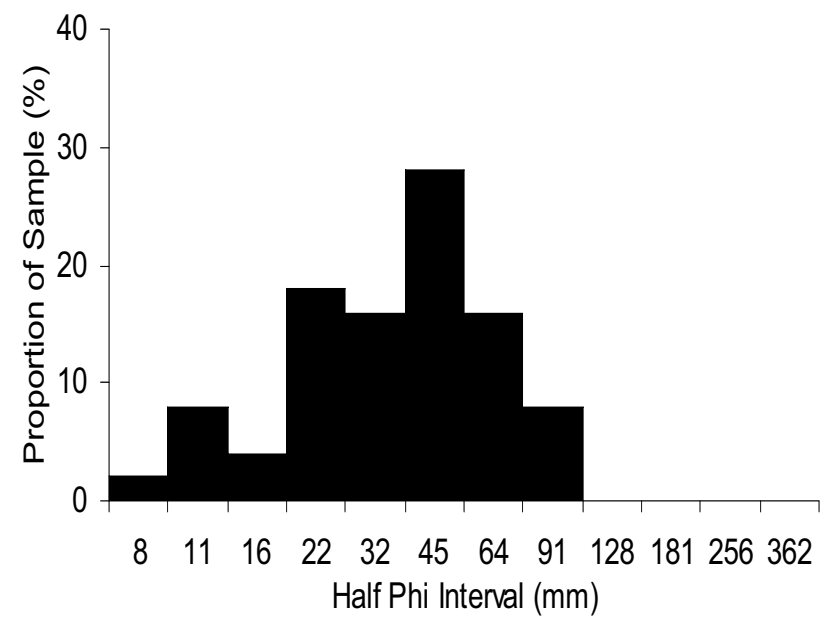

Site 21: $10.8 \mathrm{~km}$

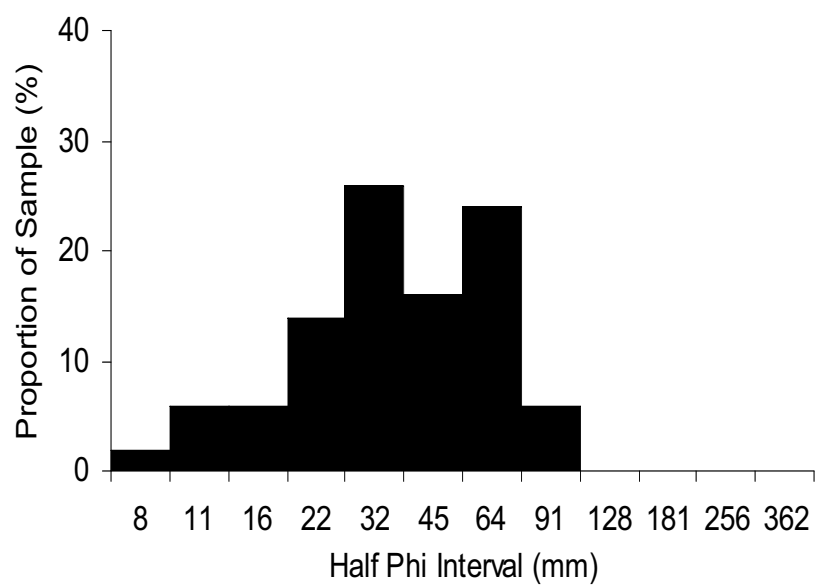

Site 22: $11.2 \mathrm{~km}$

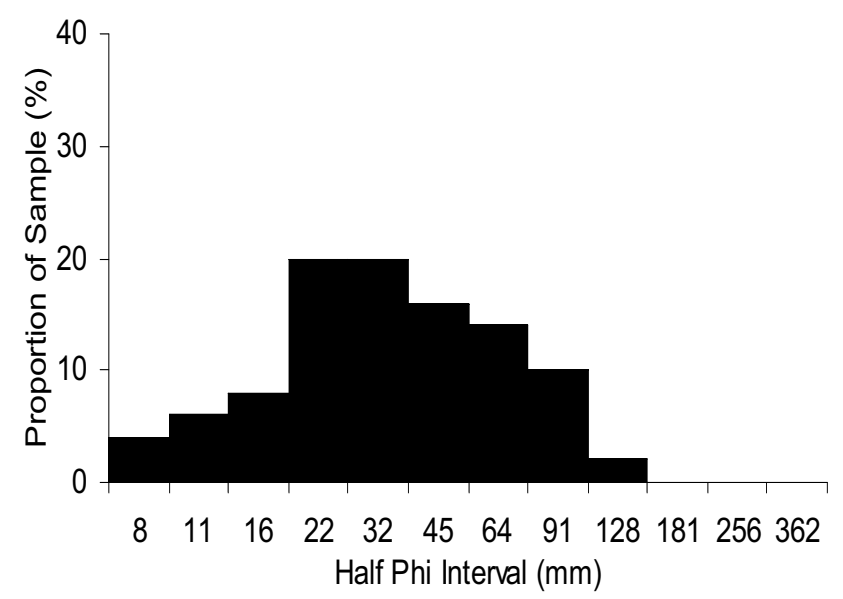

Site 23: $11.6 \mathrm{~km}$

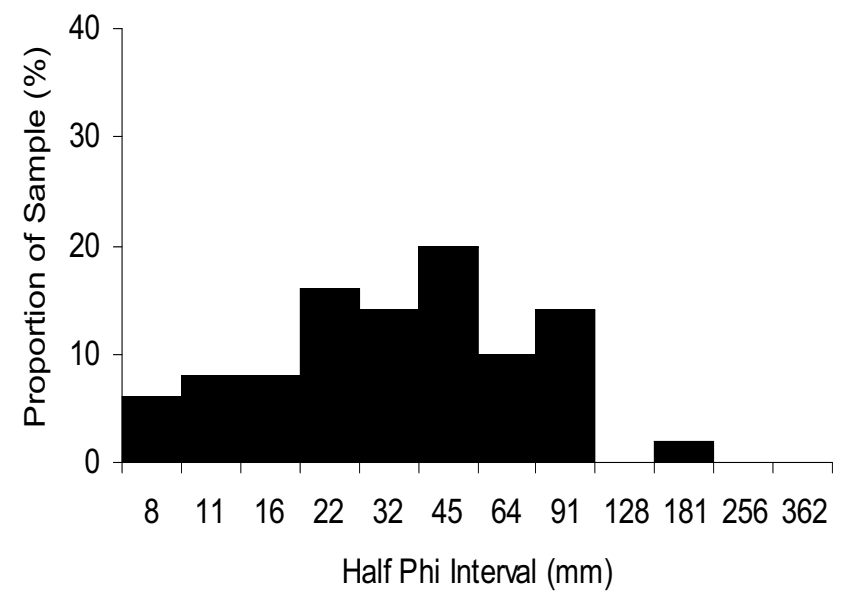

Site 24: $12.0 \mathrm{~km}$ 
(Fig. 6) contd.....

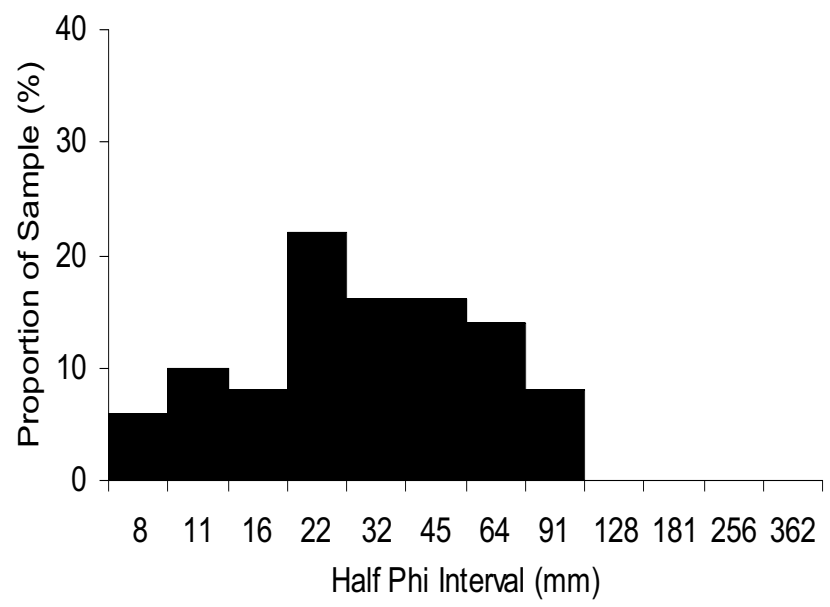

Site 25: 12.4 km

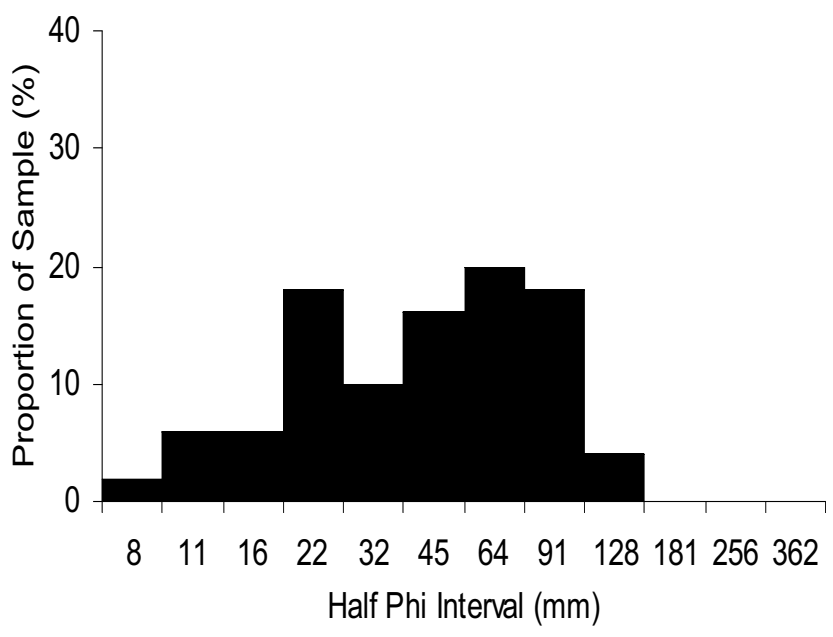

Site 26: $12.8 \mathrm{~km}$

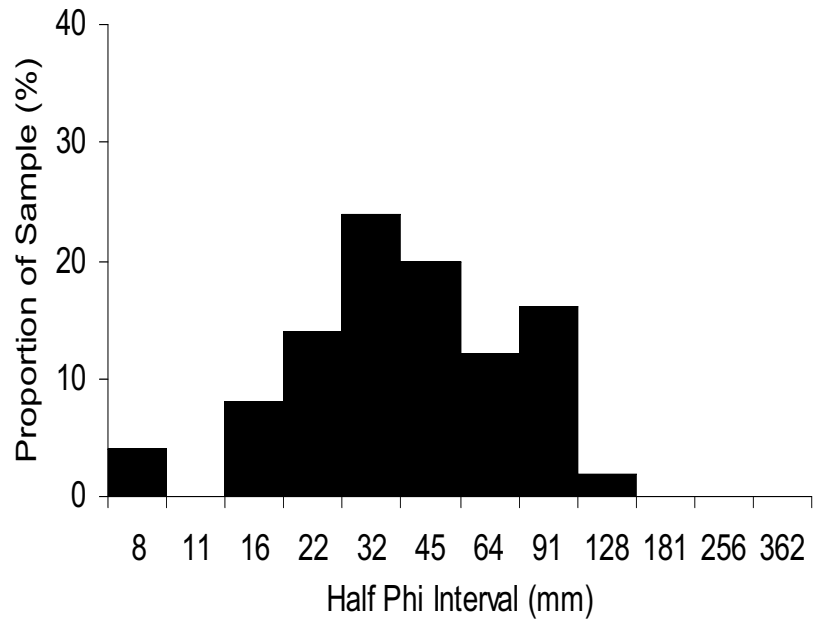

Site 27: $13.2 \mathrm{~km}$
(Fig. 6) contd.....

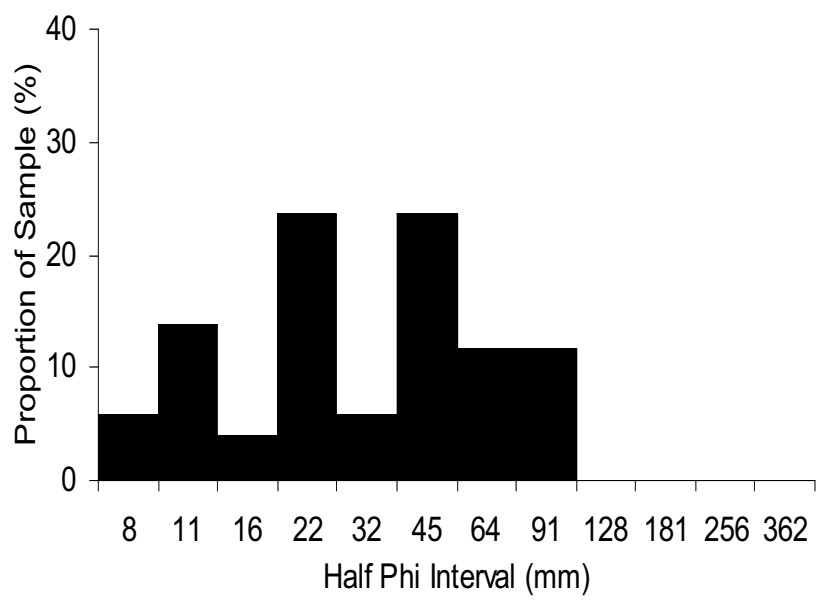

Site 28: $13.6 \mathrm{~km}$

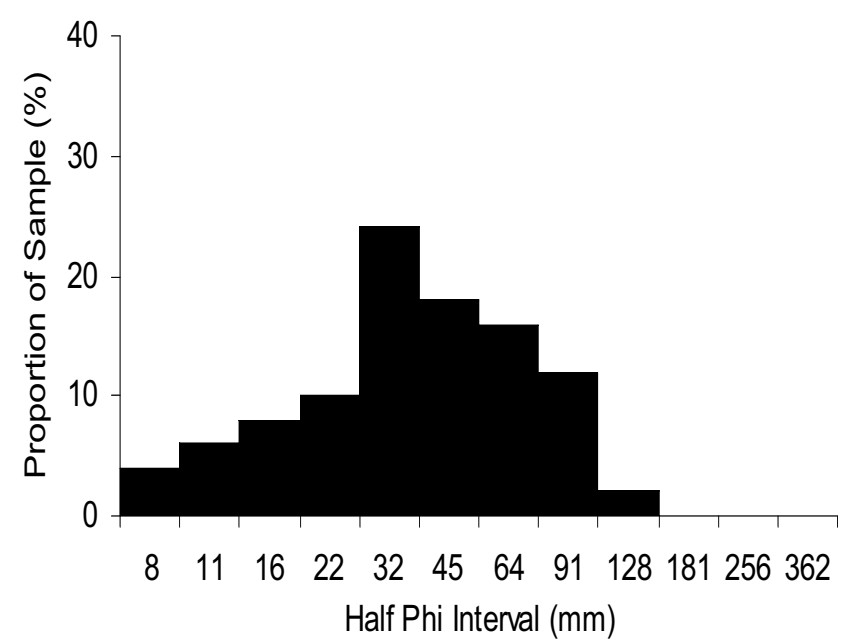

Site 29: $14.0 \mathrm{~km}$

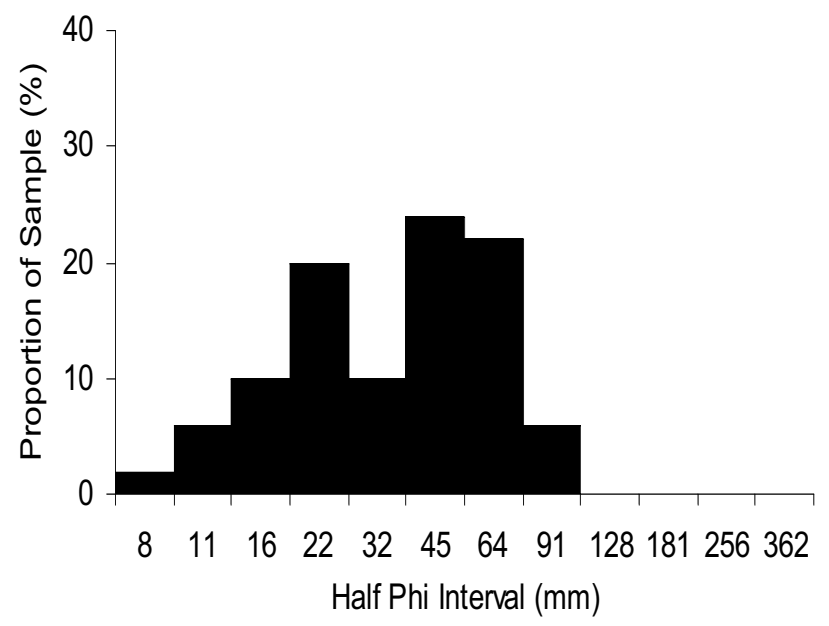

Site 30: $14.4 \mathrm{~km}$ 
(Fig. 6) contd.....

(Fig. 6) contd.....

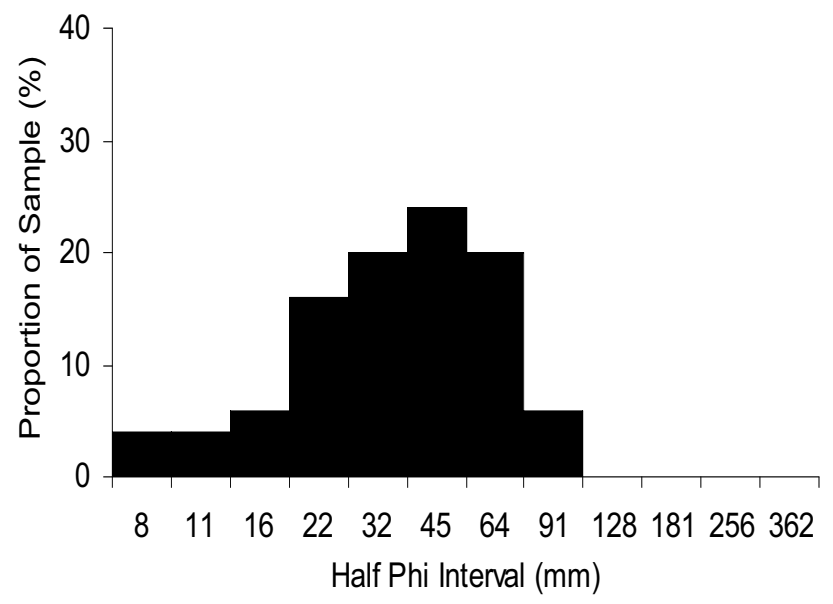

Site 31: $14.8 \mathrm{~km}$

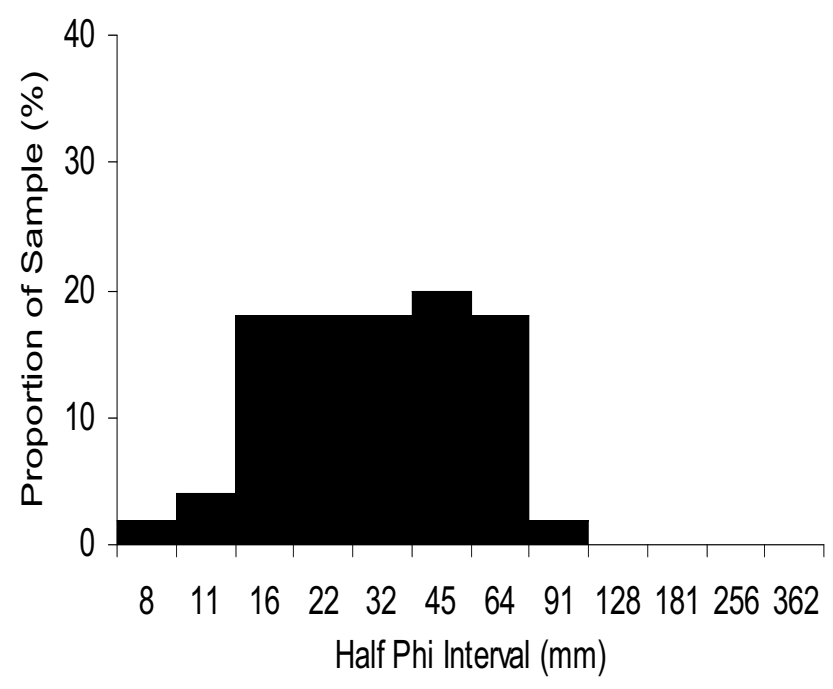

Site 32: $15.2 \mathrm{~km}$

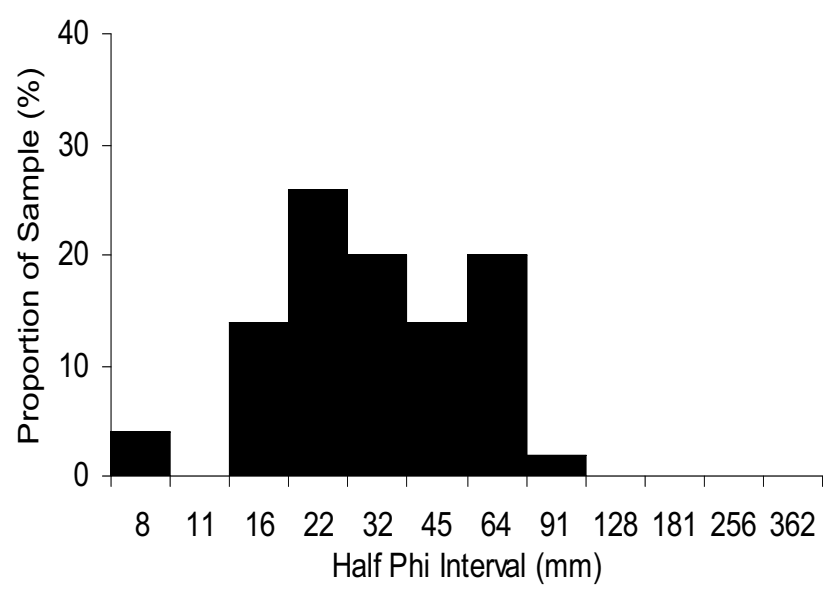

Site 33: $15.6 \mathrm{~km}$

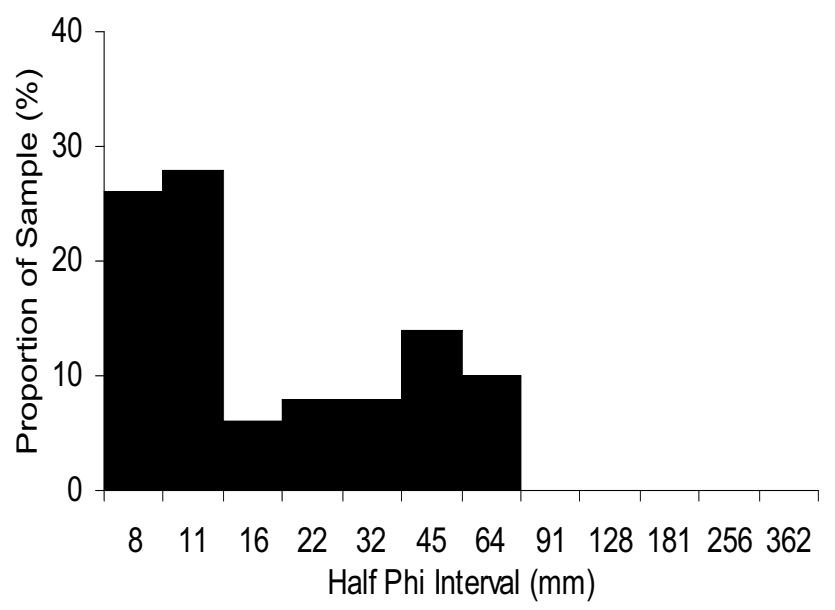

Site 34: $16.0 \mathrm{~km}$

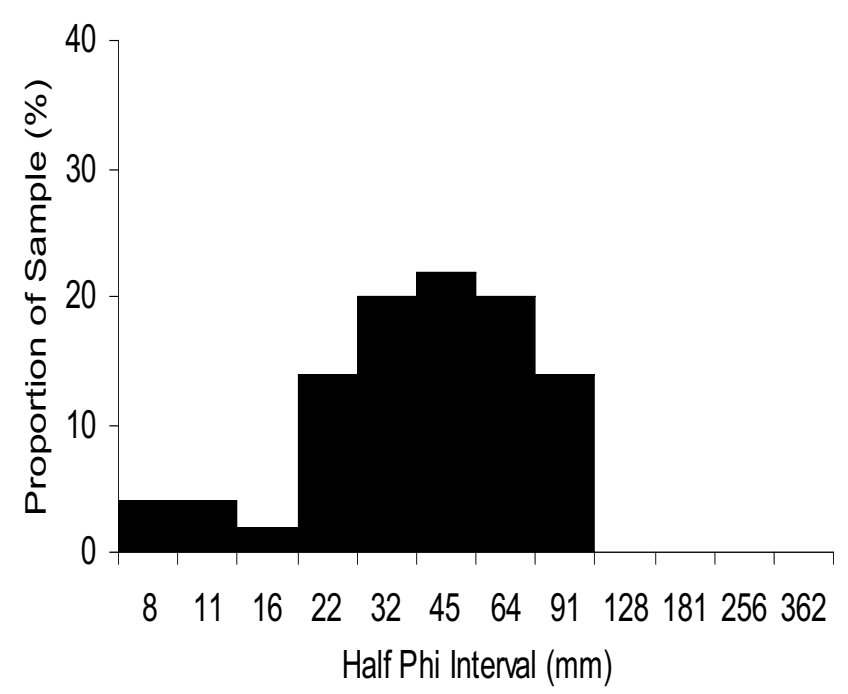

Site 35: $16.4 \mathrm{~km}$

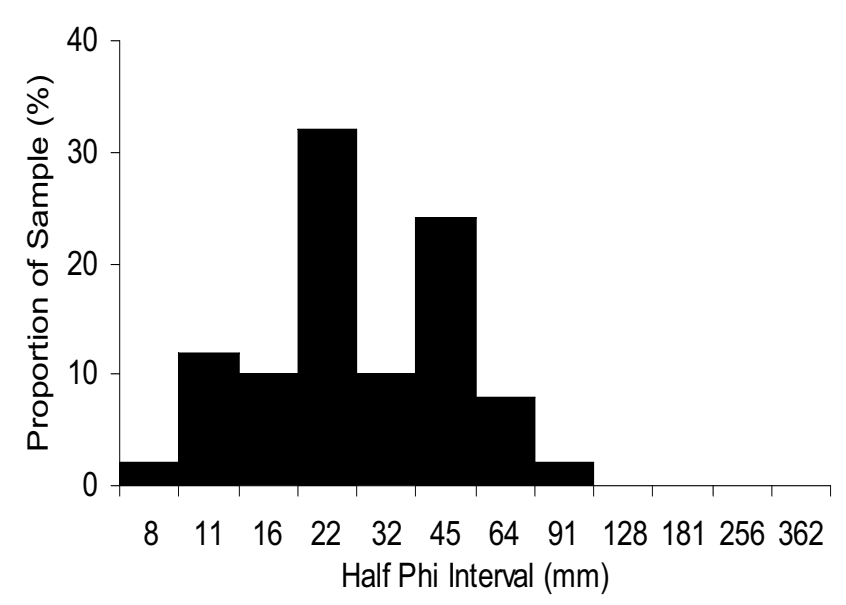

Site 36: $16.8 \mathrm{~km}$ 
(Fig. 6) contd.....

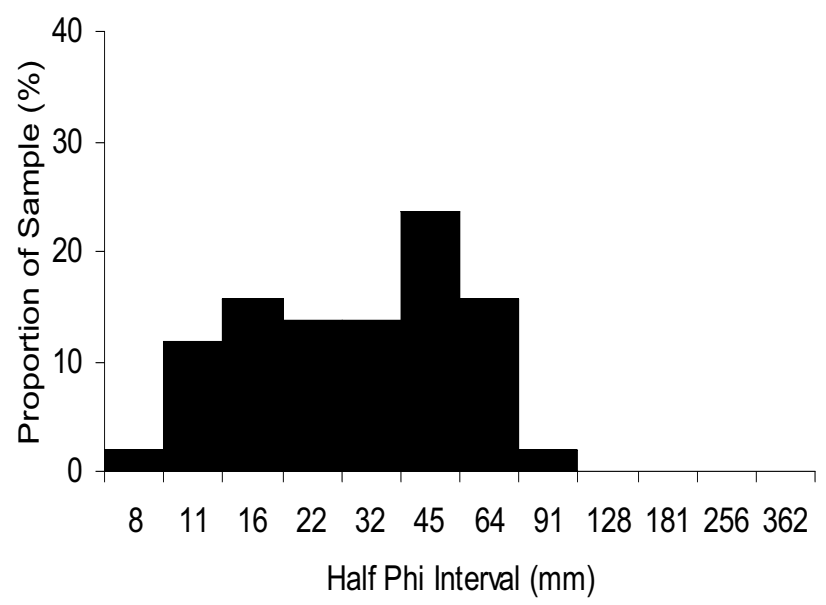

Site 37: $17.2 \mathrm{~km}$

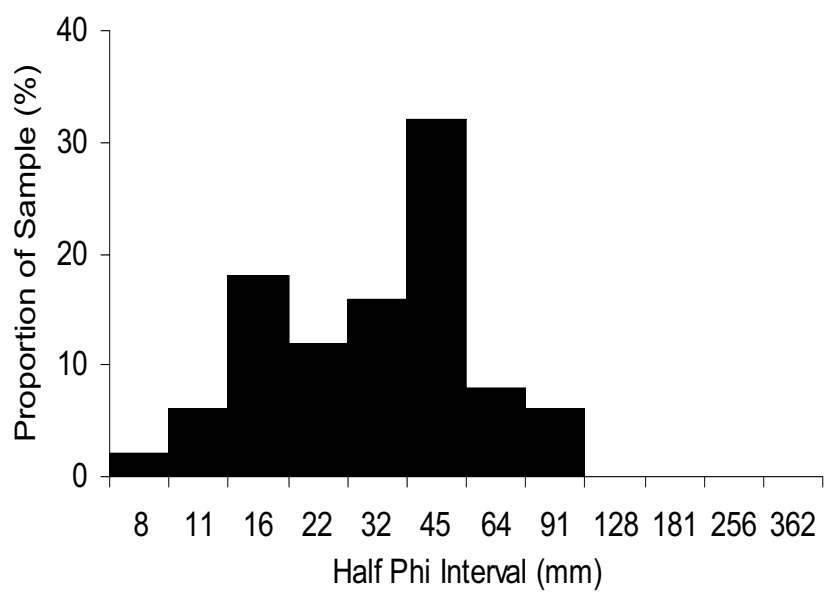

Site 38: $17.6 \mathrm{~km}$

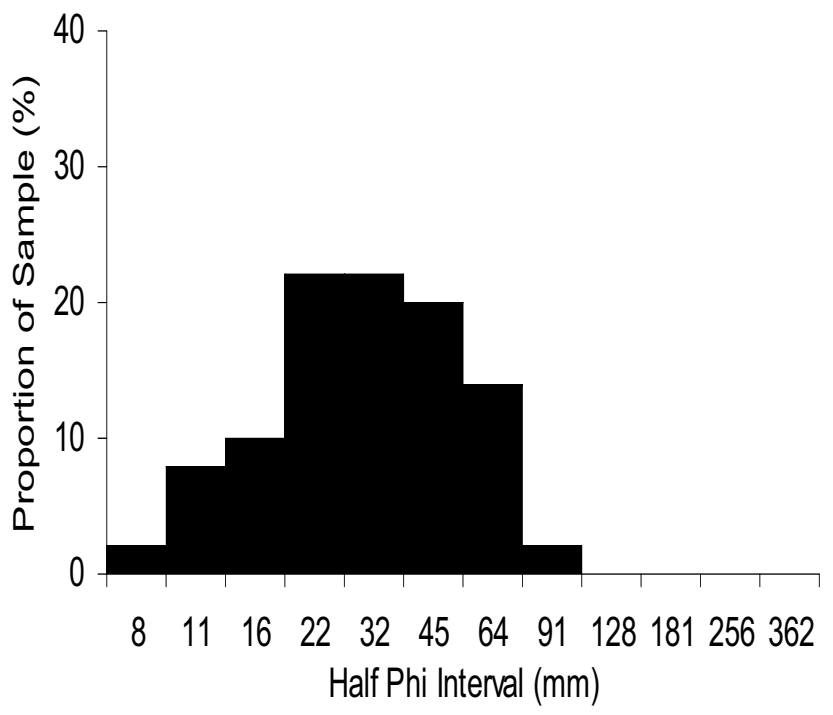

Site 39: $18.0 \mathrm{~km}$
(Fig. 6) contd.....

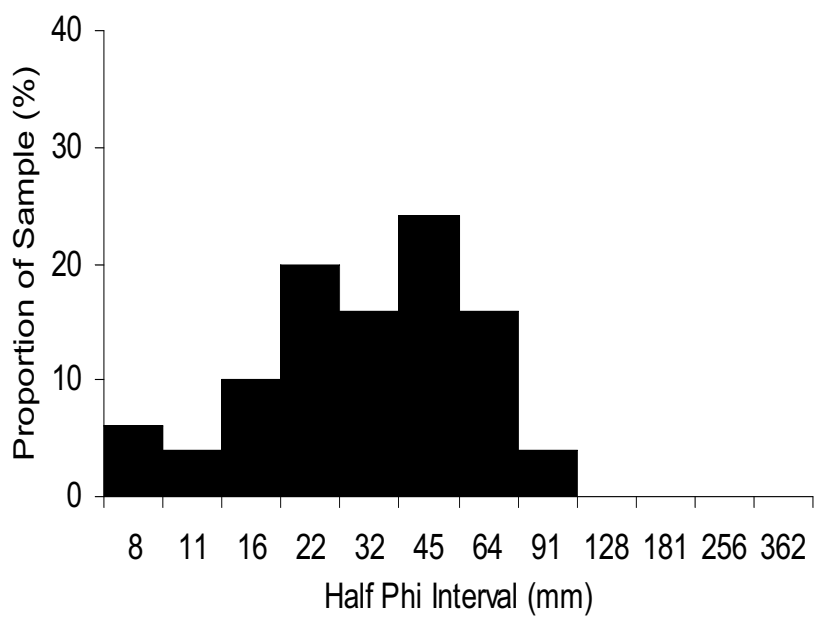

Site 40: $18.4 \mathrm{~km}$

Fig. (6). Half-phi histograms for coarsest geomorphic units. The histograms represent the shift in grain size populations downstream through the study reach and removal of coarsest fractions downstream of $6.0 \mathrm{~km}$.

Downstream fining of median grain size exhibits a relatively smooth trend through the study reach, and does not exhibit the same shift downstream of $6.0 \mathrm{~km}$ as that shown for the $\mathrm{D}_{95}$ and $\mathrm{D}_{84}$ statistics. (Figs. 4 and 5). From this, it is inferred that the $\mathrm{D}_{50}$ approximates the active (or mobile) fraction that is readily conveyed through the study reach. In contrast, $\mathrm{D}_{84}$ and the $\mathrm{D}_{95}$ statistics are much coarser in the upper $6.0 \mathrm{~km}$, indicating that these materials are conveyed downstream less readily. Preferential entrainment of the mobile fraction seemingly accounts for the transition in grain size trends around $6.0 \mathrm{~km}$. In this light, a transition from a competence-limited to a capacity-limited environment occurs as a result of the change in lateral confinement. The upstream, competence-limited environment is characterised by a coarse fabric, whereas the downstream capacity-limited environment is characterised by smaller, better-sorted clasts with a lower rate of diminution. Reduced flow competence beyond $6.0 \mathrm{~km}$ is reflected by the lack of clasts coarser than $181.0 \mathrm{~mm}$ (Fig. 6). The capacity-limited environment is characterised by a large volume of smaller, more mobile clasts, most of which can be entrained and transported by the active channel on a regular basis.

The influence of lateral confinement can be invoked to explain variability in grain size trends at more local scales. For example, Fig. (7b) indicates the local valley widening downstream of $16.0 \mathrm{~km}$ and local pinching at $17.2 \mathrm{~km}$ followed by widening. These trends are mirrored by local changes in mean grain size shown on Fig. (3), marked by transitions from $27.0 \mathrm{~mm}$ (16 km sample) to $55.6 \mathrm{~mm}(16.4$ $\mathrm{km}$ sample) to $37.8 \mathrm{~mm}$ (16.8 $\mathrm{km}$ sample).

These findings demonstrate how the increase in valley width affects the use of energy by the active channel. Lateral confinement influences the potential inundation of surfaces and the relative competence of the flow [37, 38]. More 
Table 1. Grain Size Trends of Geomorphic Units within the Study Reach

\begin{tabular}{|c|c|c|c|c|c|c|c|}
\hline Geomorphic Unit & Gravel Sheet & Ridge & $\begin{array}{c}\text { High Flow } \\
\text { Chute }\end{array}$ & Platform & Ramp & $\begin{array}{c}\text { Stabilised Gravel } \\
\text { Sheet }\end{array}$ & Stabilised Bar \\
\hline \hline $\begin{array}{c}\text { Mean Grain Size } \\
(\mathrm{mm})\end{array}$ & 36.7 & 38.5 & 37.6 & 27.8 & 51.2 & 34.8 & 44.0 \\
\hline $\begin{array}{c}\text { Range [upstream- } \\
\text { downstream] (mm) [ } \\
\mathrm{km}]\end{array}$ & $\begin{array}{c}112.0(0.7)- \\
12.6(14.7)\end{array}$ & $\begin{array}{c}90.7(1.9)- \\
20.9(13.9)\end{array}$ & $\begin{array}{c}94.4(4.7)- \\
16.0(9.9)\end{array}$ & $\begin{array}{c}37.5(12.3)- \\
18.1(16.7)\end{array}$ & $\begin{array}{c}106.5(3.9)- \\
24.2(14.7)\end{array}$ & $\begin{array}{c}70.3(5.5)- \\
15.0(17.5)\end{array}$ & $\begin{array}{c}125.7(1.1)- \\
14.6(12.3)\end{array}$ \\
\hline
\end{tabular}
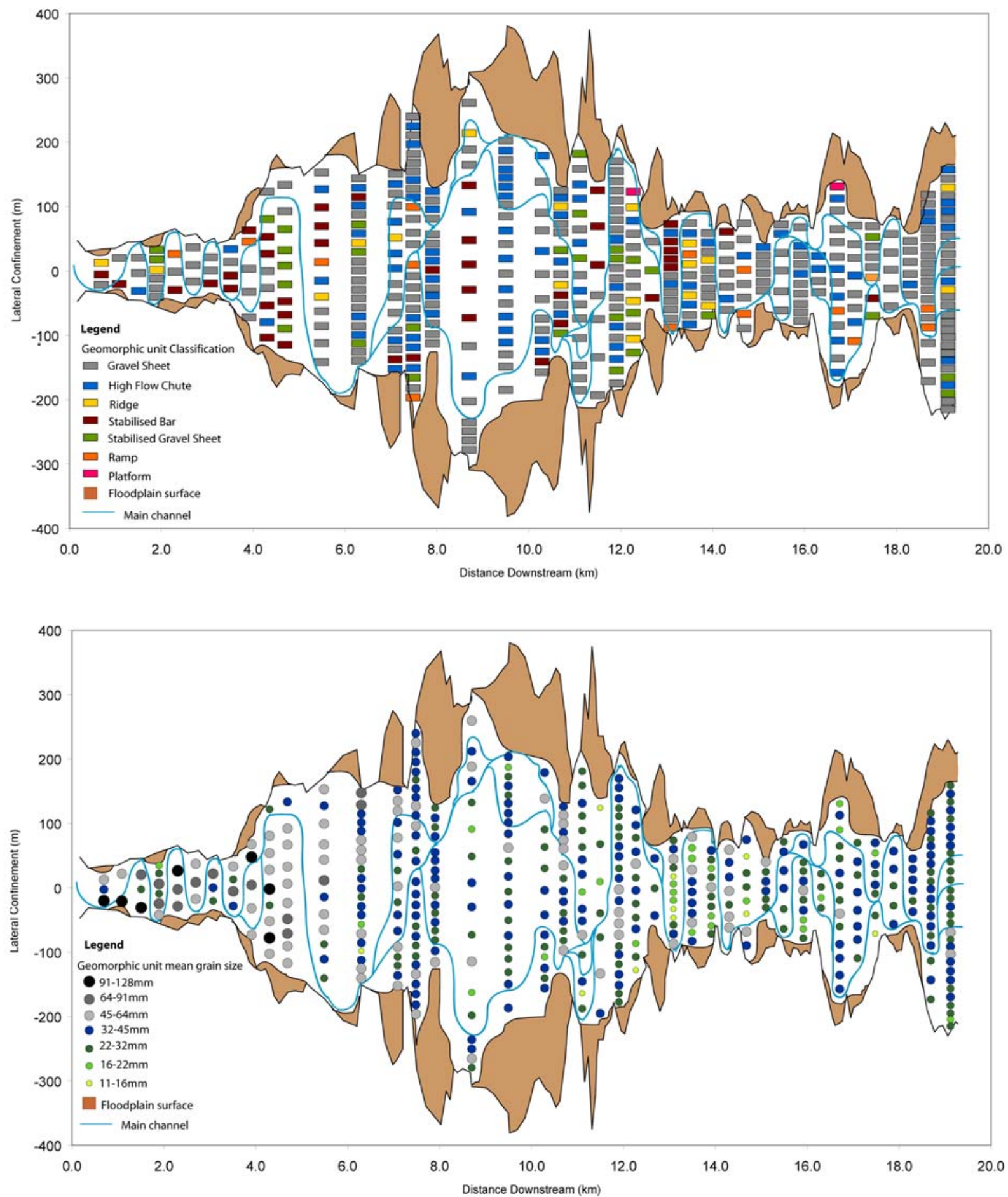

Fig. (7). The influence of downstream changes in lateral confinement upon: (a) the assemblage of geomorphic units on each cross section and (b) $0.5 \phi$ modal grain size class of each geomorphic unit. 
confined reaches are subject to greater inundation and an increased competence of flow that entrains coarser-grained sediments. In less laterally confined reaches the same flow stage inundates a larger area to a shallower depth. The competence limit at $6.0 \mathrm{~km}$ marks a shift in the geomorphic effectiveness of flow. Much greater diversity of geomorphic units is evident in the capacity-limited environment downstream of $6.0 \mathrm{~km}$ (Fig. 7a). Energy dissipation in this area results in large number of gravel sheets, high flow chute channels, ridges, platforms and ramps. The lateral variability of geomorphic units exhibits a distinct corollary with elevation, as noted for differing 'topographic levels' within the active channel zone characterized by Williams and Rust [48]. Lateral grain size trends along the lower course of the Ngaruroro River reflect the elevation and position relative to the thalweg of differing geomorphic units. The greater number of gravel sheets and high flow chutes in the less confined reach reflects the greater proportion of more mobile grain size fractions. The widest valley sections not only have the greatest width of active channel, they also have significant floodplain surfaces (Fig. 7).

The disjunct in surface grain size fractions in the study reach is generated by the differential mobility between the upstream competence-limited environment and the downstream capacity-limited environment. A schematic representation of differences between these zones is presented in Fig.
(9). The upstream, competence-limited environment is characterised by stabilised geomorphic units and a single channel. The downstream capacity-limited environment is characterized by pronounced lateral variability of shifting channels which rework a wider range of geomorphic units. Selective entrainment and hydraulic sorting result in poorly sorted geomorphic units in the confined upstream reach, which is characterised by comparatively coarse surfaces (Fig. 9a). This competence-limited environment comprises gravel sheets, stabilised bars, ridges and ramps, which are relatively elevated above the well defined channel. The downstream reach is characterised by finer-grained, well sorted, mobile geomorphic units deposited within a capacity-limited environment (Fig. 9b). Geomorphic units are dominated by gravel sheets and high flow chutes, stabilised gravel sheets and ridges and ramps, which are less elevated above the main channel and secondary channels.

Building on these findings, and the framework proposed by Lewin and Brindle [49], the impact of lateral confinement upon process-form relationships in river systems is outlined in Table 2. In this conceptualisation, primary confinement refers to bedrock-controlled river processes and forms, whereby erosive processes sculpt bedrock rivers which store negligible volumes of coarse-grained sediment while finergrained materials are flushed downstream. These gorge-like conditions were not analysed in this study. Secondary con-

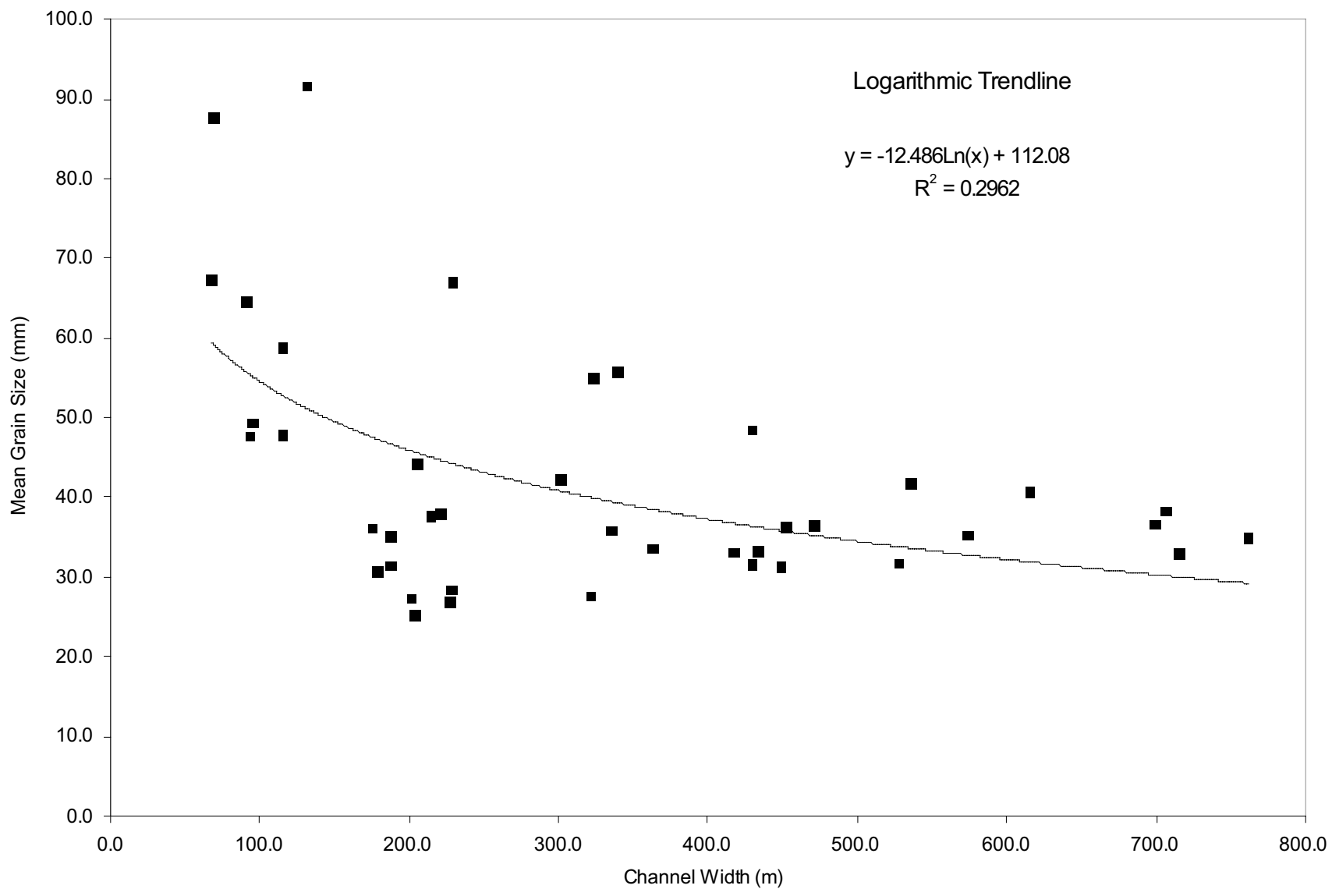

Fig. (8). The relationship between mean grain size and valley width in the study reach. The relationship of mean grain size with the varying degrees of lateral confinement is fitted with a logarithmic function relationship trendline. 


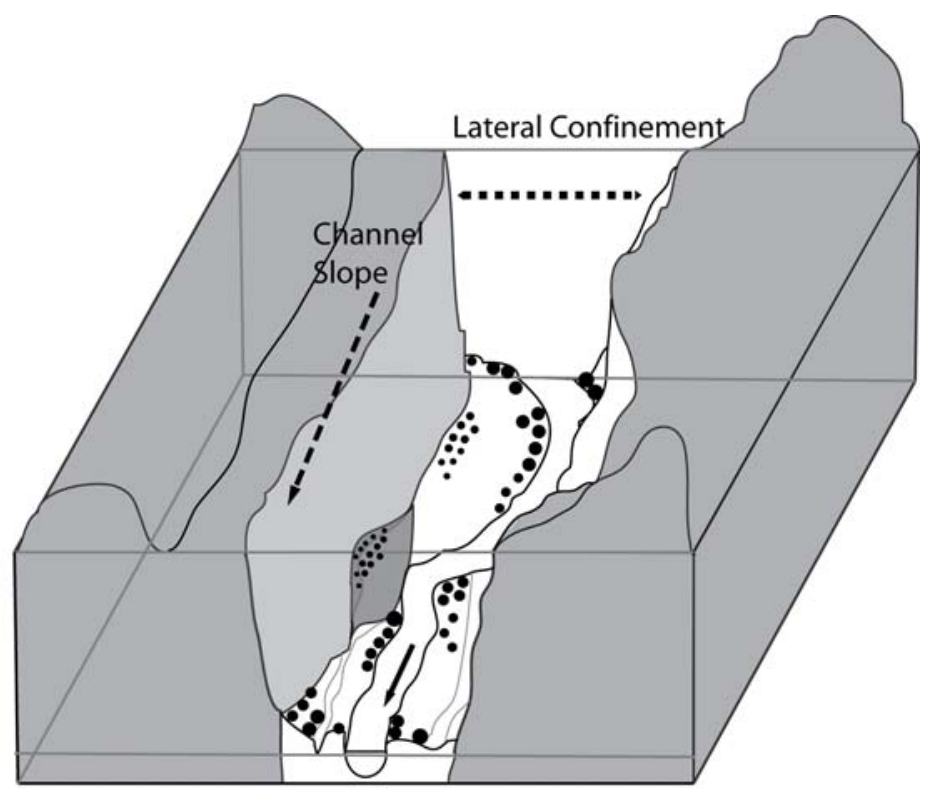

a)

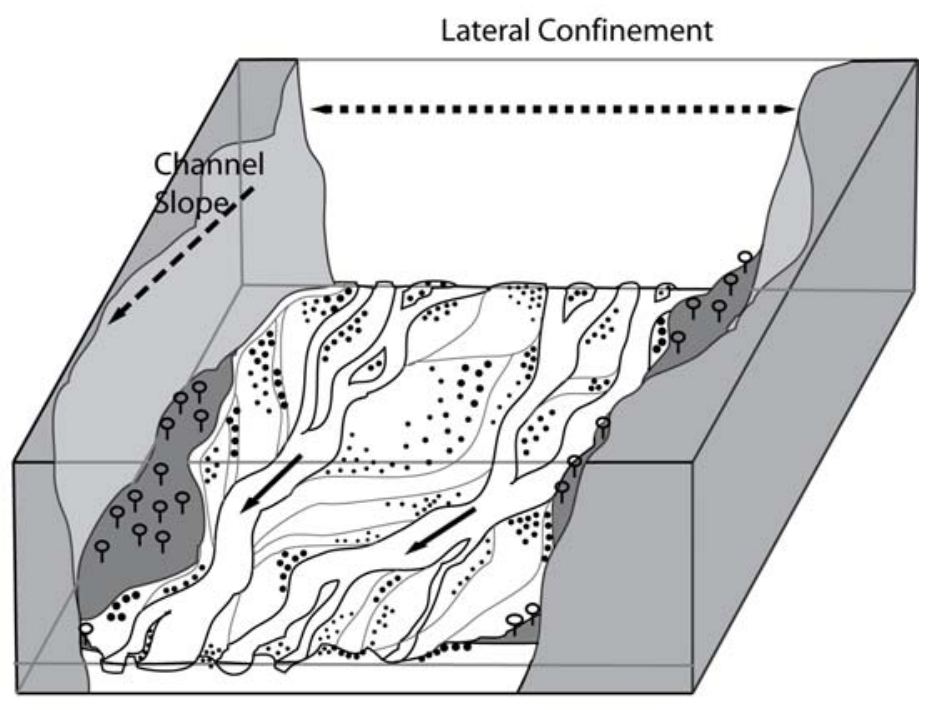

b)

Fig. (9). Schematic representation of the competence-and capacity-limited reaches (upstream and downstream of $6.0 \mathrm{~km}$ in the study reach). (a) competence-limited reach, characterized by stabilised bars, stabilised gravel sheets and coarse grained poorly sorted gravel sheets, with occasional ridges, high flow chutes, and ramps; (b) capacity-limited reach, characterized by significant lateral variability with gravel sheets, high flow chute platforms, high flow ramps and ridges, along with stabilised bars and stabilised gravel sheets. Dot-size represents grain size variation.

finement occurs in the reach immediately beyond the gorge, where terraces impose competence-limited conditions such that coarse materials are deposited upon channel-marginal geomorphic units such as alternating bars. Moving downstream along the Ngaruroro River, discontinuous floodplain pockets are considered to represent the transition to tertiary lateral confinement. In this reach, the active channel zone is notably wider than upstream. The transition to capacitylimited conditions is characterised by greater prominence of finer-grained, more mobile gravel deposits that are readily reworked at differing flow stages. Flow divides around multiple compound bars that comprise numerous gravel sheets, bar platform deposits, ridges, chute channels, and ramp deposits. Finally, laterally unconfined conditions are considered to represent quaternary confinement, whereby continuous floodplains line both channel margins under fully alluvial conditions (circumstances not encountered in this study). In some instances, human disturbance imposes lateral confinement upon channels, exemplified by the imposition of flood emban kments along the margins of the Ngaruroro River immediately downstream of the study reach. 
Table 2. Degrees of Lateral Confinement in River Systems (Adapted from [49] and [47])

\begin{tabular}{|c|c|c|c|c|}
\hline Degree & Form & Example & Process Implications & Geomorphic Units \\
\hline $1^{\circ}$ & $\begin{array}{l}\text { Comprehensive } \\
\text { confinement of } \\
\text { the active } \\
\text { channel }\end{array}$ & $\begin{array}{l}\text { Bedrock confine- } \\
\text { ment }\end{array}$ & $\begin{array}{l}\text { Competence-limited environment. Effectively } \\
\text { flushes the active fraction downstream, retaining } \\
\text { only the coarsest clasts. Bedrock resistance limits } \\
\text { valley widening. }\end{array}$ & $\begin{array}{l}\text { No floodplain. Sculpted (erosional) } \\
\text { features with temporary within-channel } \\
\text { stores of coarse grained features (e.g. } \\
\text { boulder bars). }\end{array}$ \\
\hline $2^{\circ}$ & $\begin{array}{l}\text { Effective, re- } \\
\text { strictive con- } \\
\text { finement of the } \\
\text { active channel } \\
\text { zone }\end{array}$ & $\begin{array}{l}\text { Terrace-induced } \\
\text { confinement }\end{array}$ & $\begin{array}{l}\text { Competence-limited, as confinement inhibits the } \\
\text { ability of the channel to widen, concentrating flow } \\
\text { energy. Widening of the active channel zone is } \\
\text { restricted to local undercutting of terrace deposits. }\end{array}$ & $\begin{array}{l}\text { Occasional floodplain pockets. Alternat- } \\
\text { ing bars transitional downstream to } \\
\text { instream features as the active channel } \\
\text { zone widens resulting in increasingly } \\
\text { mid-channel forms. }\end{array}$ \\
\hline $3^{\circ}$ & $\begin{array}{l}\text { Variable, dis- } \\
\text { continuous } \\
\text { confinement of } \\
\text { the active } \\
\text { channel zone }\end{array}$ & $\begin{array}{l}\text { Floodplain-induced } \\
\text { lateral confinement, } \\
\text { inset within ter- } \\
\text { races. }\end{array}$ & $\begin{array}{l}\text { The active channel zone is more readily able to } \\
\text { rework its marginal floodplain deposits, prompting } \\
\text { a transition to increasingly capacity-limited condi- } \\
\text { tions. }\end{array}$ & $\begin{array}{l}\text { Discontinuous floodplain pockets. Wider } \\
\text { array of braided and wandering gravel- } \\
\text { bed river forms (compound bars with } \\
\text { differing topographic surfaces). }\end{array}$ \\
\hline $4^{\circ}$ & $\begin{array}{l}\text { Laterally un- } \\
\text { confined }\end{array}$ & $\begin{array}{l}\text { Active channel } \\
\text { zone, freely able to } \\
\text { shift across the } \\
\text { valley floor }\end{array}$ & $\begin{array}{l}\text { Capacity-limited aggradational environment. Ex- } \\
\text { tent of reworking is flow stage dependent. Vegeta- } \\
\text { tion cover indicates the stability of differing sur- } \\
\text { faces. More stable features may locally affect the } \\
\text { position of the thalweg and secondary channels, but } \\
\text { the entire channel zone is prone to reworking. }\end{array}$ & $\begin{array}{l}\text { Continuous floodplains along both } \\
\text { channel margins. Suite of alluvial fea- } \\
\text { tures (both channel and floodplain com- } \\
\text { partments). Adjacent to active channels } \\
\text { are features such as bar platforms, gravel } \\
\text { sheets, ramp, ridge, and high flow } \\
\text { chutes. Units more distant from the } \\
\text { thalweg, or elevated above the active } \\
\text { channel, include vegetated bars, plat- } \\
\text { forms and sheets, and abandoned (sec- } \\
\text { ondary) channels. }\end{array}$ \\
\hline $\begin{array}{c}\text { Human } \\
\text { induced } \\
\text { confinement }\end{array}$ & $\begin{array}{l}\text { Imposed condi- } \\
\text { tion, designed } \\
\text { to be 'perma- } \\
\text { nent'. }\end{array}$ & $\begin{array}{l}\text { Anthropogenic } \\
\text { measures such as } \\
\text { flood emban } \\
\text { kments and chan- } \\
\text { nelisation. }\end{array}$ & $\begin{array}{l}\text { Hydraulically efficient channels that confine flow } \\
\text { energy to promote flushing of sediments and flow. }\end{array}$ & Promotes homogenous channels. \\
\hline
\end{tabular}

\section{CONCLUSION}

This research has demonstrated how lateral confinement acts alongside downstream changes in flow energy as a determinant of grain size distributions in gravel-bed rivers. In this instance, the importance of lateral confinement is illustrated by the competence to capacity shift which controls downstream fining through its affect upon hydraulic sorting. Valley confinement exerts a primary control upon the distribution of flow energy across a valley floor, affecting sediment entrainment, the distribution of geomorphic units and associated gravel organisation. Through its influence upon flow elevation and effectiveness for a given recurrence interval, lateral confinement affects the capacity of flow to entrain and mobilise differing grain size fractions, thereby fashioning process-form associations along river courses.

\section{ACKNOWLEDGEMENTS}

We thank Claire Gregory and Abigail Cowie and the willing group of Macquarie University students for their assistance in the field, Hawke's Bay Regional Council for providing flow and terrain data and facilitating access to field sites, and Nadine Trahan and Chris McDowell for assistance with diagram presentation and succinct representation.

\section{REFERENCES}

[1] T. E. Lisle, J. M. Nelson, J. Pitlick, M. A. Madej, and B. L. Barkett, "Variability of bed mobility in natural, gravel-bed channels and adjustments to sediment load at local reach scales", Water Resour. Res., vol. 36, pp. 3743-3755, Dec 2000.
[2] P. J. Ashworth, and R. I. Ferguson, "Size selective entrainment of bed load in gravel bed streams", Water Resour. Res., vol. 25, pp. 627-634, April 1989

[3] J. S. Bridge, "The interaction between channel geometry, water flow, sediment transport and deposition in braided rivers, " in Braided Rivers, J. L. Best, and C. S. Bristow, Eds. Geological Society Special Publication 75, 1993, pp. 13-71

[4] E. R. Andrews, "Entrainment of gravel from naturally sorted riverbed material", Geol. Soc. Am. Bull., vol. 94, pp. 1225-1231, Oct 1983

[5] M. Church and M. A. Hassan, "Mobility of bed material in Harris Creek”, Water Resour. Res., vol. 38, pp. 19/11-19/12, Nov 2002.

[6] R. I. Ferguson, "Hydraulic and sedimentary controls of channel pattern," in River Channels: environment and processes, K. S. Richards Ed. London: Blackwell, 1987, pp. 129-158.

[7] D. M. Powell, "Patterns and process of sediment sorting in gravelbed rivers", Prog. Phys. Geogr., vol. 22, pp. 1-32, March 1998.

[8] T. C. Gustavson, "Bed forms and stratification type of modern gravel meander lobes, Nueces River, Texas", Sedimentology, vol. 25, pp. 401-426, June 1978.

[9] D. M. Hicks and B. Gomez, "Sediment transport," in Tools in Fluvial Geomorphology, G. M. Kondolf and H. Piegay, Eds. Chichester: Wiley, 2003, pp. 425-461.

[10] M., Church and D. Jones, "Channel bars in gravel-bed rivers," in Gravel-bed Rivers, R. D. Hey, J. C. Bathurst and C. R. Thorne, Eds. Chichester: Wiley, 1982, pp. 291-323.

[11] M. Church, "Channel morphology and typology," in The Rivers Handbook, P. Calow and G. E. Petts, Ed. Oxford: Blackwell, 1992, pp. 126-143.

[12] S. A. Schumm, The Fluvial System. New York: Wiley-Interscience, 1977.

[13] A. D. Knighton, "Longitudinal changes in size and sorting of stream-bed material in four English rivers", Geol. Soc. Am. Bull., vol. 91, pp. 55-62, Jan 1980

[14] N. J. Clifford, J. Hardisty, J. R. French and S. Hart, "Downstream variation in bed material characteristics: a turbulence-controlled 
form-process feedback mechanism, "in Braided Rivers, J. L. Best, and C. S. Bristow, Eds. Geol. Soc. Spec. Pub. 75, 1993, pp. 89-104.

[15] T. E., Lisle and M. A. Madej, "Spatial variation in armouring in a channel with high sediment supply, " in Dynamics of Gravel-bed Rivers, P. Billi, R. D. Hey, C. R. Thorne and P. Tacconi, Eds. Chichester: Wiley, 1992, pp. 277-293.

[16] S. A. Schumm and M. A. Stevens, "Abrasion in place: a mechanism for rounding and size reduction of coarse sediment in rivers", Geology, vol. 1, pp. 37-40, Sept 1973.

[17] A. D. Knighton, "Longitudinal changes in the size and shape of stream bed material: evidence of variable transport conditions", Catena, vol. 9, pp. 25-34, April 1982.

[18] G. Parker and P. C. Klingeman, "On why gravel bed streams are paved”, Water Resour. Res., vol. 18, pp. 1409-1423, Oct 1982.

[19] G. J. Brierley and E. J. Hickin, "The downstream gradation of particle sizes in the Squamish River, British Columbia", Earth Surf. Processes Landform, vol. 10, pp. 597-606, Nov 1985.

[20] R. I. Ferguson, T. B. Hoey, S. Wathen and A. Werrity, "Field evidence for rapid downstream fining of river gravels through selective transport", Geology, vol. 24, pp. 179-182, Feb 1996.

[21] J. Lewin, and P. A. Brewer, "Laboratory simulation of clast abrasion”, Earth Surf. Processes Landforms, vol. 27, pp. 145-164, September 2002.

[22] R. Seal and C. Paola, "Observations of downstream fining on the North Fork Toule River near Mount St. Helens, Washington”, Water. Resour. Res., vol. 31, pp. 1409-1419, May 1995.

[23] T. B. Hoey and R. I. Ferguson, "Controls of strength and rate of downstream fining above a river base level", Water Resour. Res., vol. 33, pp. 2601-2608, Nov 1997.

[24] B. J. Bluck, "Bed forms and clast size changes in gravel-bed rivers, " in River Channels: Environment and Processes, K. S. Richards Ed. London: Blackwell, 1987, pp. 159-176.

[25] B. J. Bluck, "Structure of coarse grained braided streams", Trans. R. Soc. Edinburgh, vol. 70, pp. 181-221, April 1979.

[26] G. Parker, P. C. Klingeman and D. G. McLean, "Bedload and size distribution in paved gravel-bed streams", Journal of Hydraulic Engineering, Proceedings of the American Society of Civil Engineering, vol. 108 (HY4), pp. 544-571, Nov 1982.

[27] T. B. Hoey and R. I. Ferguson, "Numerical simulation of downstream fining by selective transport in gravel bed rivers: model development and illustrations", Water Resour. Res., vol. 30, pp. 22512260, July 1994

[28] A. Werrity, "Downstream fining in a gravel bed river in Southern Poland: lithological controls and the role of abrasion," in Dynamics of Gravel-bed Rivers, P. Billi, R. D. Hey, C. R. Thorne and P. Tacconi, Eds. Chichester: Wiley, 1992, pp. 333-346.

[29] Y. Kodama, "Downstream changes in lithology and grain size of fluvial gravels, the Watarase River, Japan: evidence of the role of abrasion in downstream fining", J. Sediment. Res., vol. 64A, pp. 68-75, Jan 1994.

[30] T. B. Hoey and B. J. Bluck, "Identifying the controls over downstream fining of river gravels", J. Sediment. Res., vol. 69, pp. 4050, Jan 1999.

[31] M. Church and R. Kellerhals, "On the statistics of grain size variation along a gravel river”, Can. J. Earth Sci., vol. 15, pp. 11511160 , July 1978 .

[32] C. Davey and M. Lapointe, "Sedimentary links and the spatial organisation of Atlantic salmon (Salmo salar) spawning habitat in a
Canadian Shield river", Geomorphology, vol. 83, pp. 82-96, August 2007.

[33] R. I. Ferguson, J. R. Cudden, T. B. Hoey and S. Rice, "River system discontinuities due to lateral inputs: generic styles and controls", Earth Surf. Processes Landforms, vol. 31, pp. 1149-1166, March 2006

[34] S. Rice, "Which tributaries disrupt downstream fining along gravelbed rivers?", Geomorphology, vol. 22, pp. 39-56, June 1998.

[35] S. Rice, "The nature and controls on downstream fining within sedimentary links", J. Sediment. Res., vol. A65, pp. 423-430, Jan 1999.

[36] S. Rice and M. Church, "Grain size along two gravel-bed rivers: statistical variation, spatial pattern and sedimentary links", Earth Surf. Processes Landforms, vol. 23, pp. 345-363, Dec 1998.

[37] F. J. Magilligan, "Thresholds and the spatial variability of flood power during extreme floods", Geomorphology, vol. 5, pp. 373390, April 1992.

[38] A. J. Miller, "Valley morphology and boundary conditions influencing spatial patterns of flood flow, " in Natural and Anthropogenic Influences in Fluvial Geomorphology, J. E. Costa, A. J. Miller, K. W. Potter and P. R. Wilcock, Eds. Washington, D. C. : Geophysical Monograph 89, 1995, pp. 57-81.

[39] C. R. Constantine, J. F. Mount and J. L. Florsheim, "The effect of longitudinal differences in gravel mobility on downstream fining pattern in the Cosumnes River, California", J. Geol., vol. 111, pp. 233-241, March 2003.

[40] N. J. Litchfield, "Maps, stratigraphic logs, and age control data for river terraces in the Eastern North Island", Lower Hutt, Institute of Geological and Nuclear Sciences, 2003.

[41] B. Segschneider, C. A. Landis, J. D. L. White, C. J. N. Wilson, and V. Manville, "Resedimentation of the $1.8 \mathrm{ka}$ Taupo ignimbrite in the Mohaka and Ngaruroro River catchments, Hawke's Bay, New Zealand", Newzeal. J. Geol. Geop., vol. 45, pp. 85-101, Sept 2002.

[42] N. J. Litchfiled and K. R. Berryman, "Correlation of fluvial terraces within the Hikurangi Margin, New Zealand: Implications for climate and baselevel controls" Geomorphology, vol. 68, pp. 291313, Jan 2005.

[43] Hawke's Bay Regional Council, "Sustainable Low Flow Project: Ngaruroro River", Hawke's Bay, Environmental Management Technical Report ISSN: 1174-3077, 1997

[44] P. D. Komar and P. A. Carling, "Grain sorting in gravel-bed streams and the choice of particle sizes for flow-competence evaluations", Sedimentology, vol. 38, pp. 489-502, June 1991.

[45] G. M. Kondolf, T. E. Lisle and M. G. Wolman, "Bed sediment measurement, "in Tools in Fluvial Geomorphology, G. M. Kondolf and H. Piegay, Ed. Chichester: Wiley, 2003, pp. 347-395.

[46] K. Bunte and S. R. Abt, "Sampling surface and subsurface particlesize distributions in wadable gravel- and cobble-bed streams for analyses in sediment transport, hydraulics, and streambed monitoring”, Rocky Mountain Research Station, United States Department of Agriculture, General Technical Report RMRS-GTR-74, 2001.

[47] G. J. Brierley, and K. A. Fryirs, Geomorphology and River Management: applications of the river styles framework. Blackwell: Oxford, 2005.

[48] P. F. Williams and B. R. Rust, "The sedimentology of a braided river”, J. Sediment. Petrol., vol. 39, pp. 649-679, June 1969.

[49] J. Lewin and B. J. Brindle, "Confined meanders, " in River Channel Changes, K. J. Gregory, Ed. Wiley: Chichester, 1977, pp. 221232 . 